Prepared in cooperation with the National Park Service

\title{
Hydrologic Characteristics and Water Quality of Headwater Streams and Wetlands at the Allegheny Portage Railroad National Historic Site, Summit Area, Blair and Cambria Counties, Pennsylvania, 2014-16
}

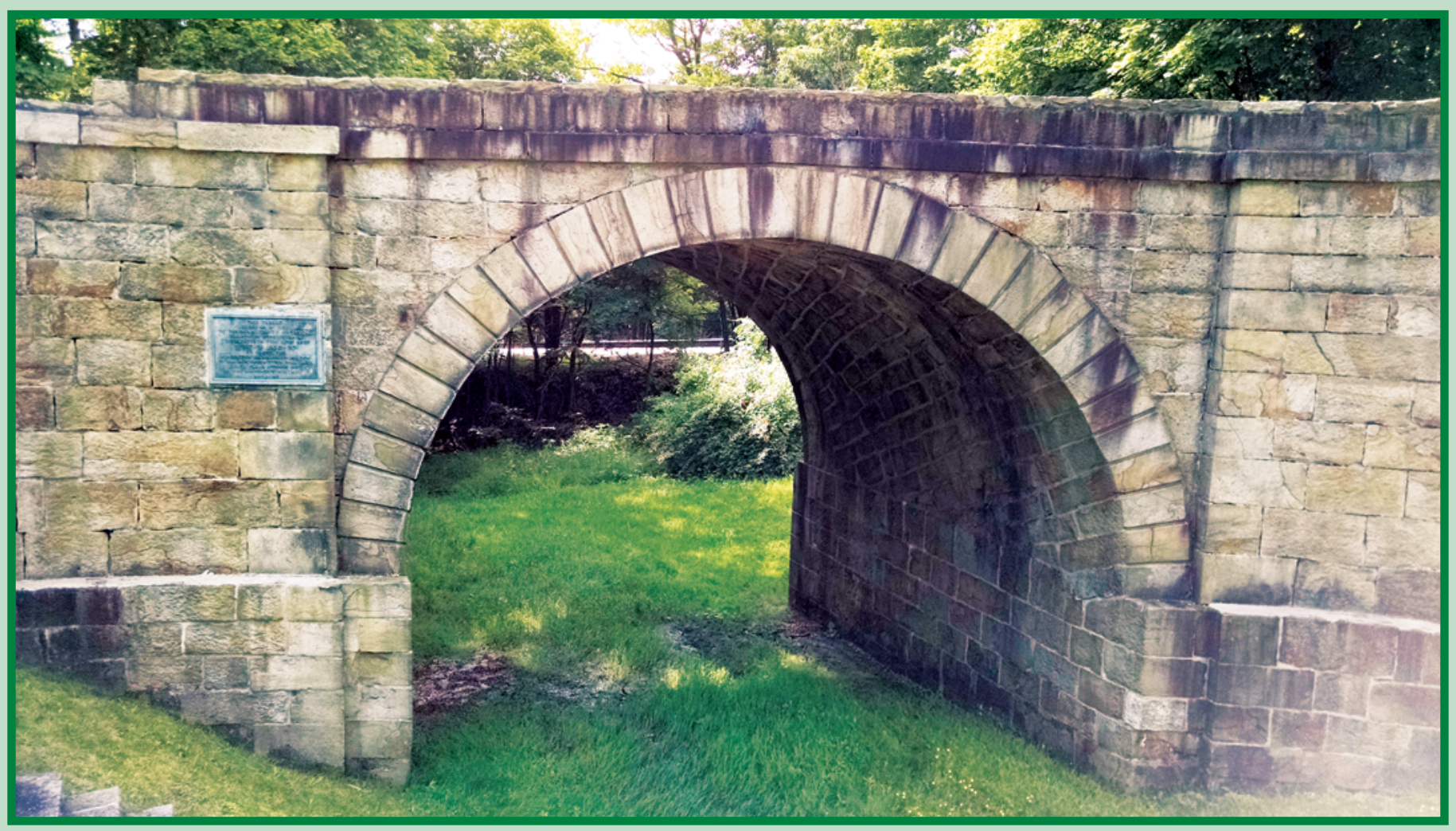

Open-File Report 2018-1125

Version 1.1, December 2018 
Cover. The Skew Arch Bridge was designed to cross over the Old Portage at the lower end of Plane 6. Built in 1833 by the Fenlon, Darlin and Kininmouth Company, it was "skewed" during construction to accommodate the oblique angle of the crossing of the Indiana, Huntingdon and Cambria Turnpike and the portage railroad. Photograph by Charles A. Cravotta III, U.S. Geological Survey. 


\section{Hydrologic Characteristics and Water Quality of Headwater Streams and Wetlands at the Allegheny Portage Railroad National Historic Site, Summit Area, Blair and Cambria Counties, Pennsylvania, 2014-16}

By Charles A. Cravotta III, Daniel G. Galeone, and Kathy A. Penrod

Prepared in cooperation with the National Park Service

Open-File Report 2018-1125

Version 1.1, December 2018 


\title{
U.S. Department of the Interior \\ RYAN K. ZINKE, Secretary
}

\author{
U.S. Geological Survey \\ James F. Reilly II, Director
}

\author{
U.S. Geological Survey, Reston, Virginia: 2018 \\ Revised: December 2018
}

For more information on the USGS —-the Federal source for science about the Earth, its natural and living resources, natural hazards, and the environment-visit https://www.usgs.gov or call 1-888-ASK-USGS.

For an overview of USGS information products, including maps, imagery, and publications,

visit https://store.usgs.gov.

Any use of trade, firm, or product names is for descriptive purposes only and does not imply endorsement by the U.S. Government.

Although this information product, for the most part, is in the public domain, it also may contain copyrighted materials as noted in the text. Permission to reproduce copyrighted items must be secured from the copyright owner.

Suggested citation:

Cravotta, C.A., III, Galeone, D.G., and Penrod, K.A., 2018, Hydrologic characteristics and water quality of headwater streams and wetlands at the Allegheny Portage Railroad National Historic Site, Summit area, Blair and Cambria Counties, Pennsylvania, 2014-16 (ver. 1.1, December 2018): U.S. Geological Survey Open-File Report 2018-1125, 21 p., https://doi.org/10.3133/ofr20181125. 


\section{Contents}

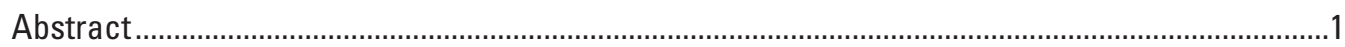

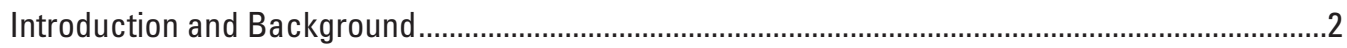

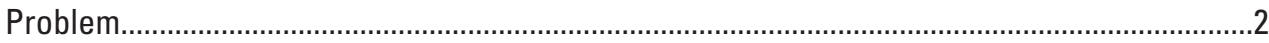

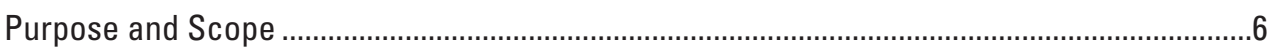

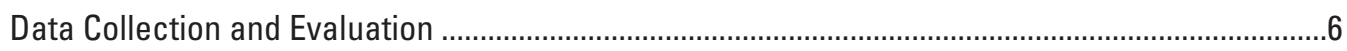

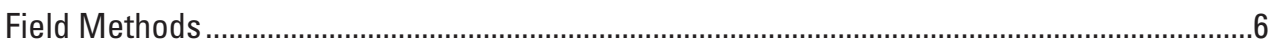

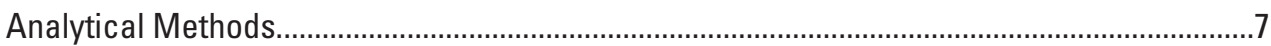

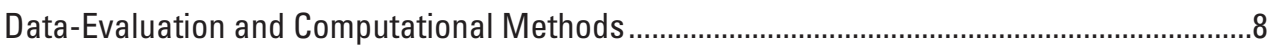

Hydrologic Characteristics of Headwater Streams and Wetlands ...............................................

Streamwater Levels and Streamflow ..............................................................................

Shallow Subsurface Water Levels..........................................................................................

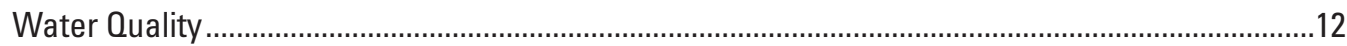

Quality Assurance and Quality Control Results .......................................................................12

Water Quality Characteristics Compared to Criteria for Protection of Aquatic Life ...............12

Ionic Contributions to Specific Conductance and Other Measures of Ionic Strength ............16

Summary and Conclusions....................................................................................................19

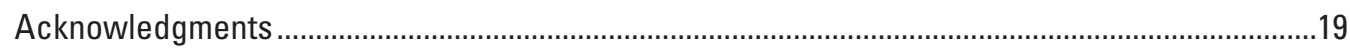

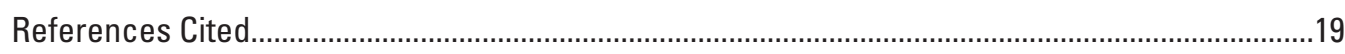

Appendix 1. Descriptions of water-quality parameters for samples collected by the U.S. Geological Survey at the ALPO Summit area, Pennsylvania, 2014-16.

Available online

Appendix 2. Synoptic water-quality data for environmental samples collected by the U.S. Geological Survey at the ALPO Summit area, Pennsylvania, 2014-16.

Available online

Appendix 3. Quality assurance quality control (OAOC) data for deionized-water blanks and U.S. Geological Survey standard reference water samples (SRWS) analyzed with environmental samples from the ALPO Summit area, Pennsylvania, 2014-16. Available online 


\section{Figures}

1. Map showing topography, bedrock geology, flooded extent of underground coal mines, and major landmarks of the Summit area of Allegheny Portage Railroad National Historic Site, Pennsylvania ...

2. Map showing streams traces in the Bradley Run and Blair Gap Run watersheds, historical underground mining, and major landmarks at the ALPO Summit area, Pennsylvania

3. Aerial photograph showing locations of mapped wetlands and seeps and associated hydrologic and water-quality monitoring sites within the Bradley Run and Blair Gap Run watersheds at the ALPO Summit area, Pennsylvania.

4. Photograph of Skew Arch Bridge showing contaminated seepage from the base of the bridge October 10, 2014, at altitude of approximately 2,120 feet NAVD 88

5. Hydrographs showing daily average stream stage at Blair Gap Run and unnamed tributary to Bradley Run compared to cumulative daily precipitation at weather station PA13 during 2015-16 at the ALPO Summit area, Pennsylvania .

6. Hydrographs showing differences between water-level altitudes in shallow and deep piezometer pairs at wetlands 3 and 6 compared to cumulative daily precipitation at weather station PA13 during 2016 at the ALPO Summit area, Pennsylvania

7. Hydrographs showing, $A$, daily average water temperature, and, $B$, differences in water temperature in shallow and deep piezometer pairs at wetlands 3 and 6 compared to daily average air temperature at weather station PA13 during 2016 at the ALPO Summit area, Pennsylvania

8. Boxplots showing selected constituent concentrations and criterion-continuous concentration thresholds for protection of freshwater aquatic life at water-quality monitoring sites, ALPO Summit area, Pennsylvania

9. Graphs showing comparison of measured and calculated values of specific conductance, total dissolved solids, osmotic pressure, and ionic strength for 41 water samples from ALPO Summit area monitoring sites, 2014-16: A, SPC calculated from ionic composition by two different methods compared to measured SPC; $B$, TDS calculated as the sum of dissolved constituent concentrations compared to calculated SPC; $C$, calculated osmotic pressure and SPC on the basis of dissolved constituent concentrations; and $D$, calculated ionic strength and SPC on the basis of dissolved constituent concentrations

10. Graphs showing major ion contributions to specific conductance for water samples from ALPO Summit area, 2014-16: $A$, ionic conductivity contributions to specific conductance of samples collected at ALPO monitoring sites in 2014-16, and $B$, average contributions by major ion species to computed SPC, expressed in percent, June 2016 


\section{Tables}

1. Sampling site descriptions and types of measurements conducted by the U.S. Geological Survey at the ALPO Summit area, Pennsylvania, 2014-16 .......................7

2. Monthly summary of logged-stage unit values at streamgages at the ALPO Summit area, Pennsylvania, May-November, 2015 and 2016 . .10

3. Summary of streamflow and water-quality characteristics for water samples from stream, seepage, and wetland sites at the ALPO Summit area, Pennsylvania, 2014-16...

Available online 


\section{Conversion Factors}

U.S. customary units to International System of Units

\begin{tabular}{|c|c|c|}
\hline Multiply & By & To obtain \\
\hline \multicolumn{3}{|c|}{ Length } \\
\hline inch (in.) & 2.54 & centimeter $(\mathrm{cm})$ \\
\hline inch (in.) & 25.4 & millimeter $(\mathrm{mm})$ \\
\hline foot $(\mathrm{ft})$ & 0.3048 & meter $(\mathrm{m})$ \\
\hline mile (mi) & 1.609 & kilometer $(\mathrm{km})$ \\
\hline \multicolumn{3}{|c|}{ Area } \\
\hline acre & 0.4047 & hectare (ha) \\
\hline acre & 0.004047 & square kilometer $\left(\mathrm{km}^{2}\right)$ \\
\hline square mile $\left(\mathrm{mi}^{2}\right)$ & 259.0 & hectare (ha) \\
\hline square mile $\left(\mathrm{mi}^{2}\right)$ & 2.590 & square kilometer $\left(\mathrm{km}^{2}\right)$ \\
\hline \multicolumn{3}{|c|}{ Volume } \\
\hline gallon (gal) & 3.785 & liter (L) \\
\hline gallon (gal) & 0.003785 & cubic meter $\left(\mathrm{m}^{3}\right)$ \\
\hline \multicolumn{3}{|c|}{ Flow rate } \\
\hline cubic foot per second $\left(\mathrm{ft}^{3} / \mathrm{s}\right)$ & 0.02832 & cubic meter per second $\left(\mathrm{m}^{3} / \mathrm{s}\right)$ \\
\hline gallon per minute (gal/min) & 0.06309 & liter per second $(\mathrm{L} / \mathrm{s})$ \\
\hline inch per day (in/day) & 2.54 & centimeter per day ( $\mathrm{cm} /$ day) \\
\hline
\end{tabular}

Temperature in degrees Celsius $\left({ }^{\circ} \mathrm{C}\right)$ may be converted to degrees Fahrenheit ( $\left.{ }^{\circ} \mathrm{F}\right)$ as follows:

$$
{ }^{\circ} \mathrm{F}=\left(1.8 \times{ }^{\circ} \mathrm{C}\right)+32 .
$$

Temperature in degrees Fahrenheit $\left({ }^{\circ} \mathrm{F}\right)$ may be converted to degrees Celsius $\left({ }^{\circ} \mathrm{C}\right)$ as follows:

$$
{ }^{\circ} \mathrm{C}=\left({ }^{\circ} \mathrm{F}-32\right) / 1.8 \text {. }
$$

\section{Datum}

Vertical coordinate information is referenced to the North American Vertical Datum of 1988 (NAVD 88).

Horizontal coordinate information is referenced to the North American Datum of 1983 (NAD 83).

Altitude, as used in this report, refers to distance above the vertical datum.

\section{Supplemental Information}

Specific conductance is given in microsiemens per centimeter at 25 degrees Celsius $\left(\mu \mathrm{S} / \mathrm{cm}\right.$ at $\left.25^{\circ} \mathrm{C}\right)$.

Concentrations of chemical constituents in water are given in either milligrams per liter (mg/L) or micrograms per liter $(\mu \mathrm{g} / \mathrm{L})$. 


\title{
Hydrologic Characteristics and Water Quality of Headwater Streams and Wetlands at the Allegheny Portage Railroad National Historic Site, Summit Area, Blair and Cambria Counties, Pennsylvania, 2014-16
}

\author{
By Charles A. Cravotta III', Daniel G. Galeone', and Kathy A. Penrod ${ }^{2}$
}

\begin{abstract}
The Allegheny Portage Railroad National Historic Site (ALPO) in Blair and Cambria Counties, Pennsylvania, protects historic features of the first railroad portage over the Allegheny Front and the first railroad tunnel in the United States. This report, which was completed by the U.S. Geological Survey in cooperation with the National Park Service, summarizes water resources in the headwaters of the Blair Gap Run and Bradley Run watersheds at the ALPO Summit area during 2014-16. These new baseline data fill an existing gap in knowledge and may be helpful to evaluate potential changes in the hydrologic characteristics of streams and associated wetlands at the Summit area.

Results of synoptic water-quality surveys and continuous stage records at two streamgages near the headwaters of Blair Gap Run and Bradley Run indicate that the headwater streams of the ALPO Summit area are perennial but have different water-quality characteristics. The water sampled in the headwaters of Blair Gap Run had $\mathrm{pH}$ that ranged from acidic to near neutral, combined with elevated concentrations of dissolved solids, mainly sulfate, chloride, and sodium. These characteristics can be attributed to drainage from legacy coal mines and runoff from nearby roads treated with deicing salt. More than once during the study, the chloride and associated contaminant concentrations in tributaries of Blair Gap Run exceeded chronic thresholds for protection of freshwater aquatic organisms. In contrast, the water quality at tributaries of Bradley Run in the Summit area was characterized by near-neutral $\mathrm{pH}$ and relatively low concentrations of dissolved constituents, which met criteria for protection of freshwater aquatic life. By comparison, the deep groundwater discharged as abandoned mine drainage to Sugar Run from the Argyle Stone Bridge Mine, which underlies the Summit area, had
\end{abstract}

\footnotetext{
${ }^{1}$ U.S. Geological Survey.
}

${ }^{2}$ National Park Service, Allegheny Portage Railroad National Historic Site. acidic $\mathrm{pH}$ and elevated concentrations of sulfate and metals, which exceeded chronic and acute thresholds for aquatic life.

Data on shallow groundwater levels in piezometers at two wetlands in the Summit area, which were monitored during spring through fall of 2016, indicate downward hydraulic gradients (higher water level in shallow piezometer than in deeper piezometer) and potential for local groundwater recharge during rainfall events, particularly in the summer and fall seasons. The wetlands in the upland area (wetland 3, at altitude 2,370 feet NAVD 88) near the divide between Blair Gap Run and Bradley Run between the Lemon House and Picnic Area, exhibited a consistent downward gradient from spring through fall of 2016. The associated surface seepage at wetland 3 dried up in the summer of 2016. In contrast, the wetlands in the adjoining valley (wetland 6, at altitude 2,198 feet NAVD 88) in the northwestern Summit area exhibited upward hydraulic gradients in the spring and produced continuous seepage. Despite downward gradients during summer and fall, the seepage associated with wetland 6 sustained perennial conditions in the Bradley Run drainage through the summer of 2016.

Differences in groundwater altitudes and associated water quality among the surface water, shallow groundwater, and deep groundwater in the Summit area imply that the surface water and shallow groundwater in the Summit area could recharge the groundwater of the underlying coal mines. Seasonally upward and downward vertical gradients in the nearsurface soil and bedrock at wetland 6, and unimpaired water quality in the Bradley Run headwaters, are consistent with a perched water table and local hydrology that is influenced by local recharge. Persistent downward gradients and impaired water quality at wetland 3 and the adjacent headwaters seeps and tributaries of Blair Gap Run could be attributed to subsidence and drainage from shallow coalbeds (Upper Freeport, seam E) and associated mine workings in that area; however, the underlying deep coal mine pool (Lower Kittanning, seam B), which is hundreds of feet below the surface, does not appear to affect the hydrologic characteristics of the headwater streams and wetlands in the Summit area. 


\section{Introduction and Background}

The Allegheny Portage Railroad National Historic Site (ALPO) in Blair and Cambria Counties, Pennsylvania, consists of two separate units (fig. 1, inset map). The Main Unit consists of the Summit area and the Incline, spanning approximately 8 miles between Cresson, Cambria County, and Duncansville, Blair County. The Staple Bend Tunnel Unit (SBTU) is 16 miles southwest of the Main Unit in Mineral Point near Johnstown, Cambria County.

The mission of ALPO is to protect remaining historic features of the first railroad portage over the Allegheny Front and the first railroad tunnel in the United States. The Allegheny Portage Railroad was open to the public between 1834 and 1854 to portage sectional canal boats and passenger cars across the Allegheny Mountains between Hollidaysburg and Johnstown, Pennsylvania, completing canal/rail service between Philadelphia and Pittsburgh (National Park Service, 2016).

The ALPO Main Unit includes the Visitor Center, Lemon House, Engine House 6 Ruins and Exhibit Shelter, and Skew Arch Bridge in the Summit area (fig. 1), as well as Incline 6, Level 6, and the 6 to 10 Hiking/Biking trail. The SBTU features the 2-mile-long Staple Bend Tunnel Trail following the historic railroad trace to the Staple Bend Tunnel, the first railroad tunnel in the United States. A water-resources survey at the SBTU was completed by U.S. Geological Survey (USGS) in 2005 (Cravotta, 2005).

\section{Problem}

Legacy coal mines affect the surface and subsurface hydrology at the ALPO Summit area. The ALPO Summit area is underlain by Mississippian and Pennsylvanian age sedimentary bedrock (fig. 1). The coal-bearing Pennsylvanian Allegheny Formation (Pa in fig. 1) crops out along the Allegheny Front and dips northwestward beneath the Summit area (Glover, 1990). At the ALPO Visitor Center, the Upper Freeport coal (E seam) is approximately $40-45$ feet below the ground surface, and the Lower Kittanning coal (B seam) is approximately 200 feet below the surface (Pennsylvania Department of Environmental Protection, 2015). Both coal beds were extensively mined by room-and-pillar methods during the late 1800s through World War II (Cloues, 1992).

The Tunnel Coaling Mine was developed in the Upper Freeport coal (E seam), which has a thickness of about 5 feet, and the Argyle Stone Bridge Mine was developed within the Lower Kittanning coal (B seam) (fig. 2), which has a thickness between 3 and 5 feet at the Summit area (Cloues, 1992). Although the adits and shafts were sealed after the mines closed, because of the high extraction ratio and deterioration of the remaining coal pillars, surface subsidence features developed decades later (Cloues, 1992). Various wetlands at the Summit area (fig. 3) could be associated with subsidence and seepage from abandoned shafts, adits, or other structures. For example, perennial seepage at the base of Skew Arch Bridge produces an orangish-brown precipitate that is characteristic of iron-laden coal-mine drainage (fig. 4). Nevertheless, details on the quantity and quality characteristics of the local water resources have not been documented.

The ALPO Summit area includes the headwaters of Blair Gap Run and Bradley Run (figs. 1-3), which are designated cold-water fisheries (CWF) (Commonwealth of Pennsylvania, 2011a). These headwaters streams and associated wetlands and seeps could provide critical habitat for aquatic biota, including invertebrates, amphibians, reptiles, brook trout and other fish (Sharpe and others, 2012), but have not been included in previous aquatic quality monitoring efforts by the National Park Service (NPS). Prior water-quality monitoring by NPS included field water-quality, macroinvertebrate, and fish surveys along Blair Gap Run downstream of Skew Arch Bridge (Sheeder and Tzilkowski, 2006; Tzilkowski and others, 2011; Yetter and others, 2013). The macroinvertebrate sampling indicated water-quality impairment in headwaters of Blair Gap Run, but did not identify specific chemical constituents that may affect the aquatic life.

The Pennsylvania Department of Environmental Protection (PaDEP) intends to extract contaminated groundwater from the Argyle Stone Bridge Mine beneath the ALPO Summit area (Pennsylvania Department of Environmental Protection, 2015). This mine pool water will be pumped from a borehole in tract 106-04 in the northern section of the ALPO Summit area (figs. 2 and 3), diverted off site, and combined with water from two other mine pools for centralized treatment at a newly constructed acid-mine drainage (AMD) treatment facility near Cresson, Pa. Tract 106-04 (National Park Service, 2014) is owned by the Federal government and administered by NPS but is located outside the current legislated boundary for ALPO (Roger Johnson, NPS, written commun., 2018).

The AMD from the Argyle Stone Bridge Mine pool currently discharges north of the ALPO Summit area into Sugar Run (fig. 1). Pumping of the Argyle Stone Bridge Mine pool is intended to decrease the mine pool altitude to a level below the current Sugar Run AMD discharge altitude (2,061 feet NAVD 88) and, consequently, eliminate that AMD. In 2014, the NPS requested the preparation of an environmental assessment by PaDEP and has since granted permission for the installation of an extraction well, injection well, and associated pipeline within the ALPO Summit area, which includes the NPS-administered tract 106-04 (Pennsylvania Department of Environmental Protection, 2015). At the same time, the NPS requested technical assistance from the USGS to document existing water quantity and quality characteristics at the ALPO Summit area prior to any such pumping and diversion. The hydrologic information would fill a data gap to (1) determine if the Summit area wetlands and associated headwater streams are naturally perennial or intermittent and (2) provide a baseline for future evaluation of the effects of mine-pool pumping on these freshwater aquatic resources. 


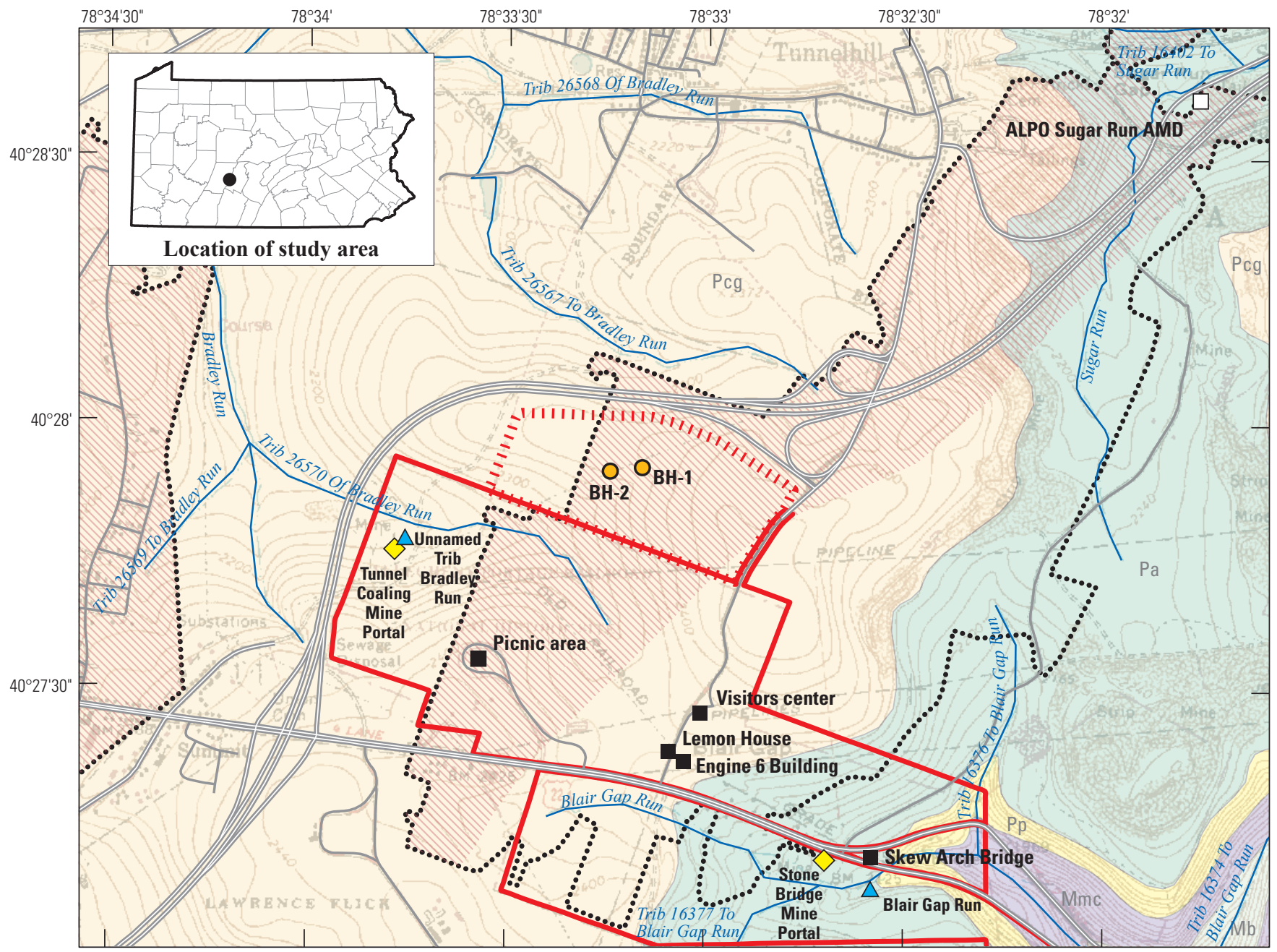

Base modified from U.S. Geological Survey Cresson, PA, 1:24,000, 1981

Geology from Pennsylvania Department of Conservation and Natural Resources, 2001
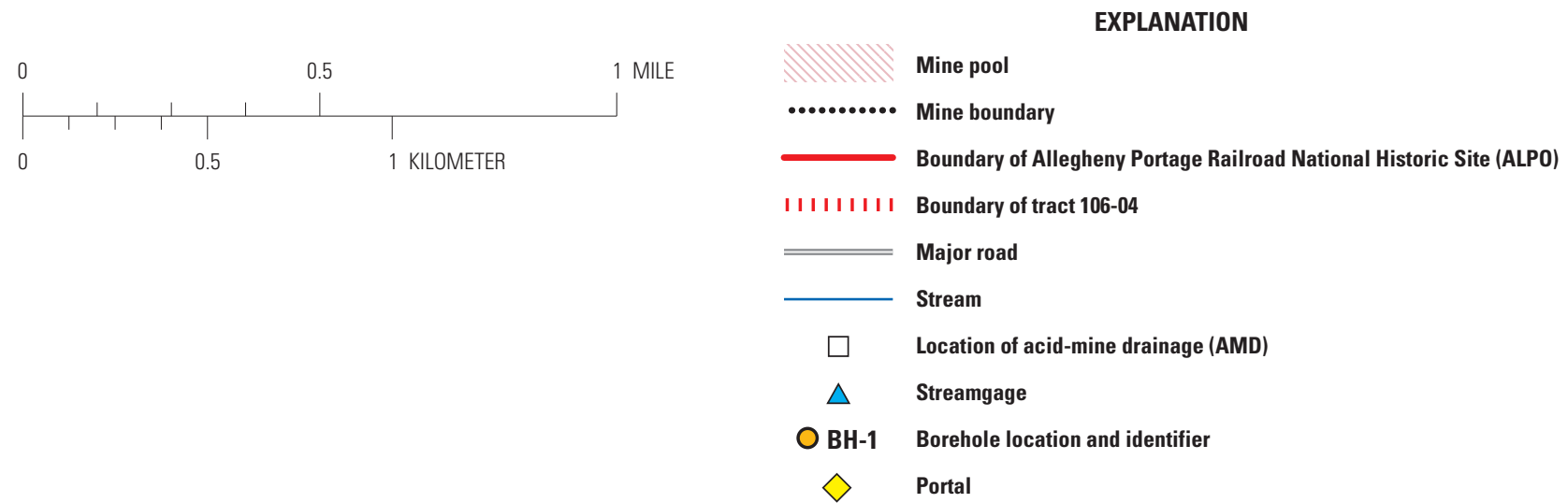

Figure 1. Topography, bedrock geology, flooded extent of underground coal mines, and major landmarks of the Summit area of Allegheny Portage Railroad National Historic Site (ALPO), Pennsylvania. Bedrock base is from Pennsylvania Department of Conservation and Natural Resources (2001): geologic units, in order of oldest to youngest, are as follows: Mauch Chunk Formation (Mmc); Burgoon Sandstone (Mb); Pottsville Formation (Pp); Allegheny Formation (Pa); Glenshaw Formation (Pcg). Boundary and extent of flooding (mine pool) of underground mines within Lower Kittanning coal (B seam) from Pennsylvania Department of Environmental Protection (2015). Stream traces showing local names are approximately located. Dashed red boundary line identifies tract 106-04, which is owned by the Federal government and administered by the National Park Service but located outside the current legislated boundary for ALPO. 


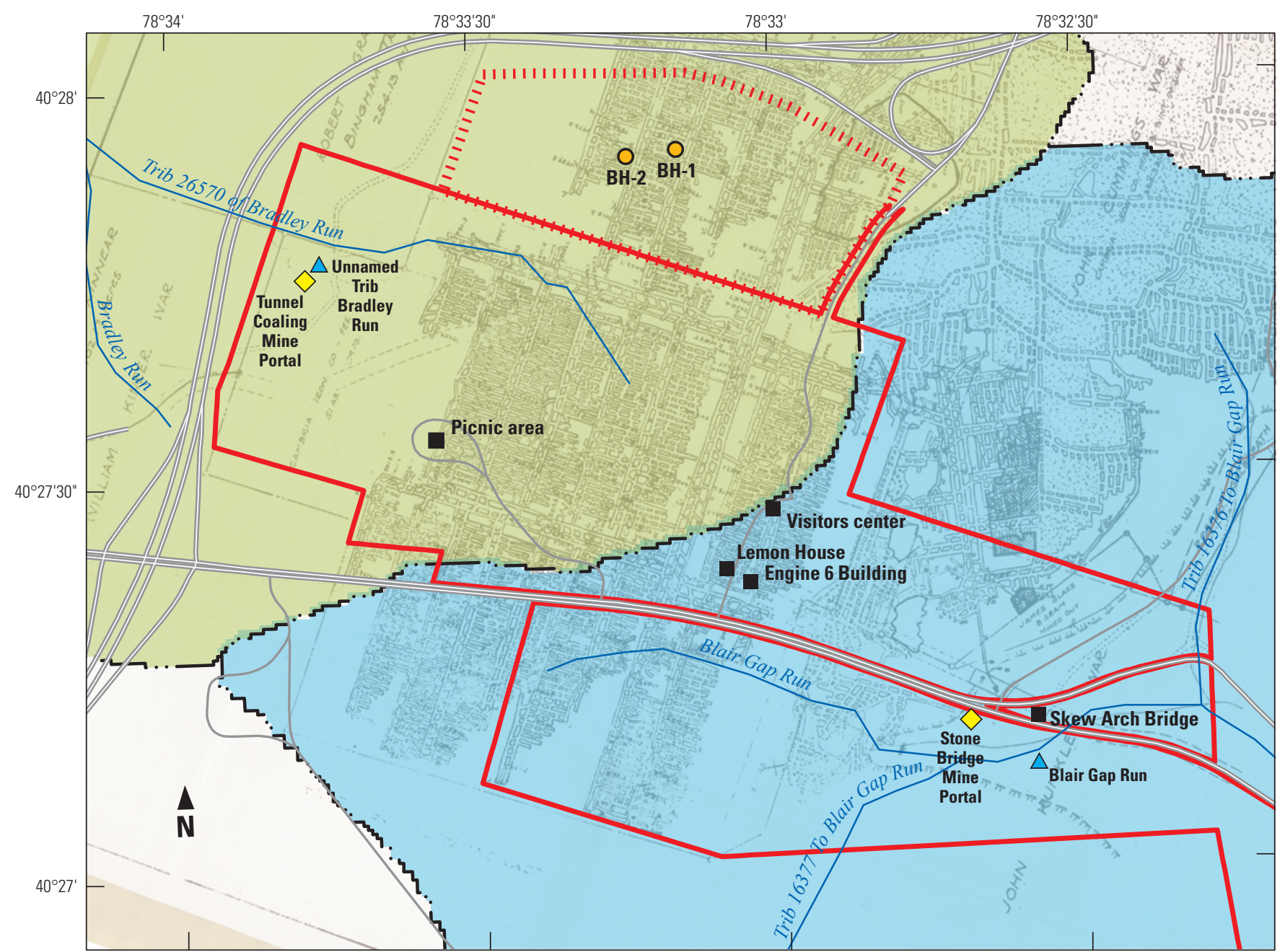

Base modified from Pennsylvania State University, 2014

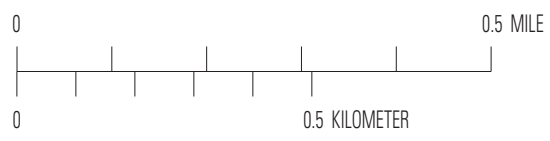

5 MILE

0.5 KILOMETER

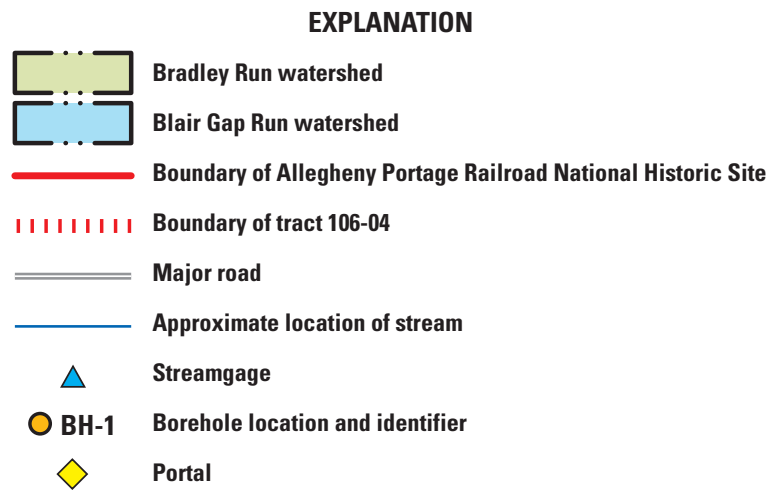

Figure 2. Stream traces in the Bradley Run and Blair Gap Run watersheds (shaded areas), historical underground mining, and major landmarks at the ALPO Summit area, Pennsylvania. Basemap is the scanned and approximately georeferenced 1952 map of the Argyle Coal Bennington 8 underground mine on the Lower Kittanning coal (B seam) (Pennsylvania State University, 2014). 


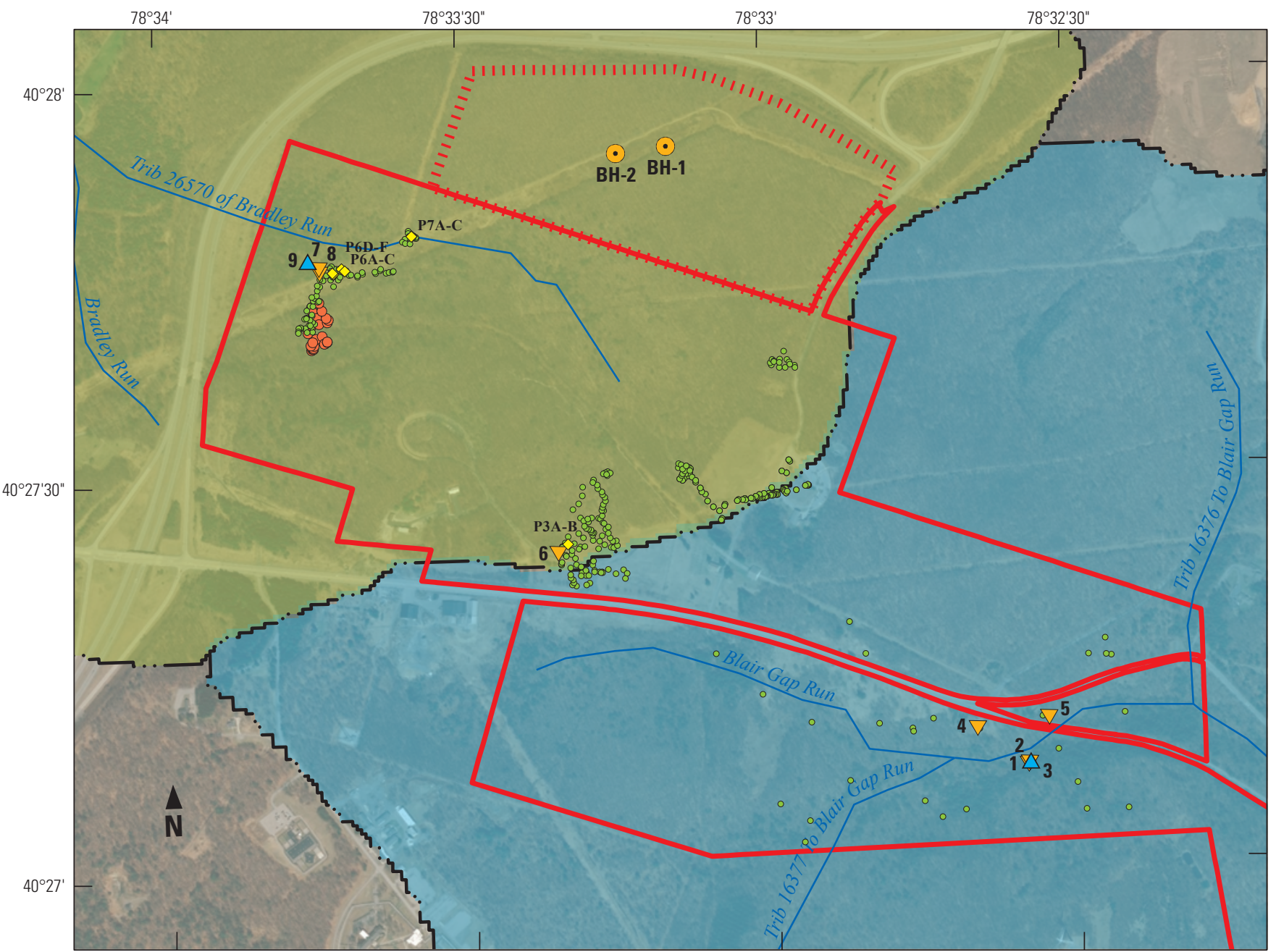

Base map image is the intellectual property of Esri and is used herein under license. Copyright (C) 2018 Esri and its licensors. All rights reserved.

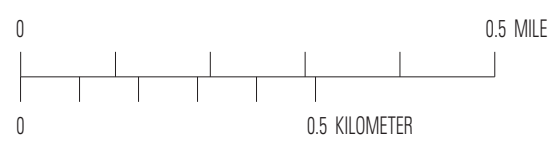

\section{EXPLANATION}

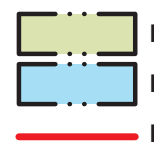

Bradley Run watershed

Blair Gap Run watershed

Boundary of Allegheny Portage Railroad National Historic Site

| | | | | | | | | Boundary of tract 106-04

Approximate location of stream

$\triangle 3$ Streamgage and identifier-Identifier shown in table 1

O BH-1 Borehole location and identifier

$\nabla 4 \quad$ OW sample and identifier-Identifier shown in table 1

$\diamond$ P3A-B Piezometer and identifier-Identifier shown for selected sites and shown in table 1

- Seep

- Wetland

Figure 3. Locations of mapped wetlands and seeps and associated hydrologic and water-quality monitoring sites within the Bradley Run and Blair Gap Run watersheds at the ALPO Summit area, Pennsylvania. Seeps and wetlands from Sharpe and others (2012). Monitoring site numbers and descriptions are given in table 1. 


\section{Purpose and Scope}

The purpose of this report is to summarize the existing hydrologic conditions at the ALPO Summit area prior to extraction and transfer of groundwater from underground mines beneath the area to the Cresson AMD Treatment Plant. Synoptic field surveys were completed by the USGS in cooperation with the NPS during 2014-16, to acquire data on surface-water quantity and quality for a range of hydrologic conditions, with an emphasis on base flow. Hydrologic data described in this report are included in a separate data release (Cravotta and others, 2018) and in appendixes 1-3, available online at https://doi.org/10.3133/ofr20181125.

\section{Data Collection and Evaluation}

To document discharge duration, discharge quality, and potential relations among surface water and shallow groundwater resources at the ALPO Summit area, a hydrologic monitoring network with continuous stage recorders was installed by USGS with assistance from NPS. Data on the flow rates, water levels, and compositions of streamwater and associated seepage and wetland water in the Summit area were collected primarily during base-flow conditions from the spring through fall seasons of 2014-16 at selected monitoring sites (table 1). Methods used to collect and evaluate these data are summarized below.

\section{Field Methods}

Hydrologic data collection by USGS began in April 2014 and continued intermittently through December 2016. Streamgages were established in June 2014 at the headwaters of Blair Gap Run and the unnamed tributary 26570 of Bradley Run (fig. 3). A staff plate and submersible, vented pressure transducer (Heron Nano dipperLogger) were installed near the deepest section of a selected pool to monitor stream stage and determine if the stream was perennial or intermittent at each gage location. Additionally, to indicate the temporal variability in shallow groundwater levels and vertical hydraulic gradients at seeps and wetlands near the streamgages, drivepoint piezometers (Solinst stainless steel) were installed in June 2014 and October 2015 near the outflow locations of wetland 3 (piezometers P3A-B), in uplands (altitude 22,370 feet NAVD 88) near the drainage divide between Blair Gap Run and Bradley Run, and at wetlands 6 and 7, in the adjacent valley (altitudes 22,180-2,200 feet NAVD 88) near the headwaters of Bradley Run (piezometers P6A-C, P6D-F, and P7A-C) (fig. 3). Two or more piezometers of different length were installed at each wetland. Selected piezometers at wetlands 3 and 6 were equipped with submersible, unvented pressure transducers (Schlumberger microDiver) and barometric pressure (Schlumberger baroDiver) recording devices (table 1). Data from the transducers were downloaded periodically, and

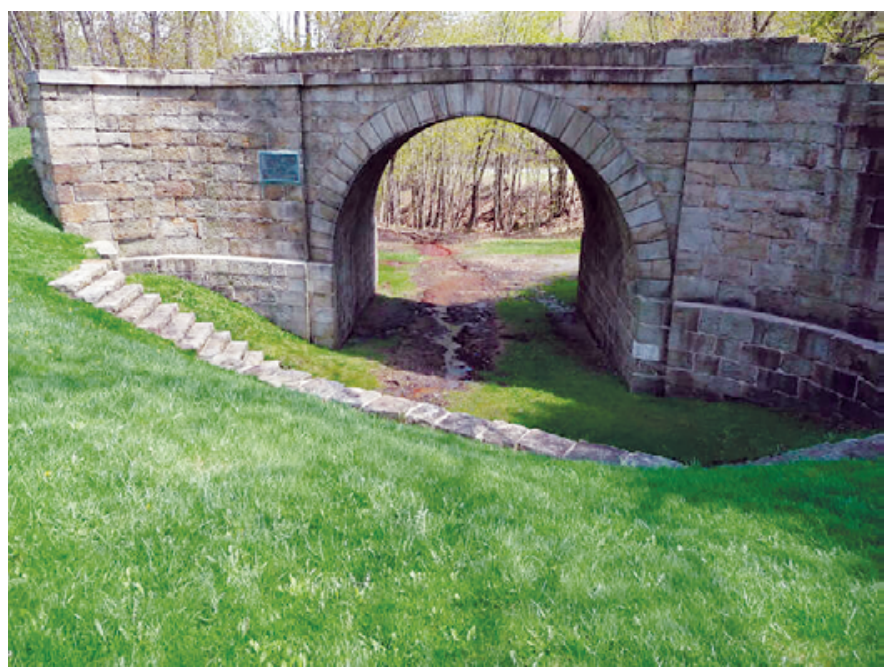

Figure 4. Skew Arch Bridge showing contaminated seepage from the base of the bridge October 10,2014, at altitude of approximately 2,120 feet NAVD 88. Photograph by Kathy A. Penrod, National Park Service.

the transducers were removed during winter to avoid potential damage from freezing.

The locations of each gage and piezometer nest were determined using a hand-held global positioning system (GPS). The corresponding altitude at the land surface was then estimated from light detection and ranging (lidar) data (Pennsylvania Department of Conservation and Natural Resources, 2015a,b). The depth to water in piezometers was measured periodically using a zero-displacement electric tape while the transducer remained in place. Water-level altitude inside the piezometer was computed as the water column height recorded by the transducer added to the altitude at the bottom of the piezometer.

During 2014-16, synoptic surveys were conducted by the USGS, with assistance from NPS, to obtain data on stream flow or stage and the corresponding water quality over a range of hydrologic conditions. The synoptic surveys typically included measurements of the water level at piezometers and streamgages, plus stream flow at the gages and associated tributary, seepage, or wetland sites. At each sample site, temperature, $\mathrm{pH}$, specific conductance (SPC), dissolved oxygen (DO), and redox potential (Eh) were measured using a multiparameter, submersible sonde (YSI 556 MPS) calibrated in the field in accordance with standard field methods (U.S. Geological Survey, variously dated). Field $\mathrm{pH}$ and Eh were determined using a combination $\mathrm{Pt}$ and $\mathrm{Ag} / \mathrm{AgCl}$ electrode with a $\mathrm{pH}$ sensor. The electrode was calibrated in $\mathrm{pH} 4.0,7.0$, and 10.0 buffer solutions and in ZoBell's solution (U.S. Geological Survey, variously dated). Values for Eh were corrected to $25^{\circ} \mathrm{C}$ relative to the standard hydrogen electrode in accordance with methods of Nordstrom (1977). The Eh data were used to 
Table 1. Sampling site descriptions and types of measurements conducted by the U.S. Geological Survey at the ALPO Summit area, Pennsylvania, 2014-16.

[USGS, U.S. Geological Survey; latitude and longitude in decimal degrees; ft, feet; Q, instantaneous discharge; QW, instantaneous water quality; S, instantaneous stage; L, continuously logged stage or water level; n.a., not applicable; Trib, tributary; AMD, acid mine drainage]

\begin{tabular}{|c|c|c|c|c|c|}
\hline Site description & USGS station ID & Latitude & Longitude & Measurements & Map number ${ }^{1}$ \\
\hline Blair Gap Run & 01555851 & 40.452 & -78.543 & $\mathrm{Q}, \mathrm{QW}, \mathrm{S}, \mathrm{L}$ & 1 \\
\hline Blair Gap Run South Fork & 0155585066 & 40.452 & -78.543 & Q, QW & 2 \\
\hline Blair Gap Run North Fork & 0155585077 & 40.452 & -78.543 & $\mathrm{Q}, \mathrm{QW}$ & 3 \\
\hline Seep 2 & 402710078324001 & 40.453 & -78.545 & $\mathrm{Q}, \mathrm{QW}$ & 4 \\
\hline Skew Arch Bridge & 402711078323301 & 40.453 & -78.543 & $\mathrm{Q}, \mathrm{QW}$ & 5 \\
\hline Wetland 3 & 402724078332001 & 40.457 & -78.556 & $\mathrm{Q}, \mathrm{QW}$ & 6 \\
\hline Wetland 7 & 402746078334402 & 40.463 & -78.524 & $\mathrm{Q}, \mathrm{QW}$ & 7 \\
\hline Wetland 6 & 402746078334401 & 40.463 & -78.562 & Q, QW & 8 \\
\hline Unnamed Trib Bradley Run & 01541307 & 40.463 & -78.563 & Q, QW, S, L & 9 \\
\hline Sugar Run AMD & 402837078314601 & 40.477 & -78.529 & $\mathrm{Q}, \mathrm{QW}$ & 10 \\
\hline Piezometer $6 \mathrm{~A} 1(4.5 \mathrm{ft})^{2}$ & n.a. & 40.463 & -78.562 & $\mathrm{~S}, \mathrm{~L}$ & P6A-C \\
\hline Piezometer 6A2 (2.5 ft) & n.a. & 40.463 & -78.562 & $\mathrm{~S}$ & P6A-C \\
\hline Piezometer 6B (4.5 ft) & n.a. & 40.463 & -78.562 & $\mathrm{~S}, \mathrm{~L}$ & P6A-C \\
\hline Piezometer $6 \mathrm{C} 1(4.5 \mathrm{ft})$ & n.a. & 40.463 & -78.562 & $\mathrm{~S}, \mathrm{~L}$ & P6A-C \\
\hline Piezometer 6C2 (2.5 ft) & n.a. & 40.463 & -78.562 & $\mathrm{~S}, \mathrm{~L}$ & P6A-C \\
\hline Piezometer 6D (6.5 ft) & n.a. & 40.463 & -78.562 & $\mathrm{~S}$ & P6D-F \\
\hline Piezometer $6 \mathrm{E}(6.5 \mathrm{ft})$ & n.a. & 40.463 & -78.562 & $\mathrm{~S}, \mathrm{~L}$ & P6D-F \\
\hline Piezometer $6 \mathrm{~F}(6.5 \mathrm{ft})$ & n.a. & 40.463 & -78.562 & $\mathrm{~S}$ & P6D-F \\
\hline Piezometer 7A1 (5.5 ft) & n.a. & 40.463 & -78.560 & $\mathrm{~S}$ & P7A-C \\
\hline Piezometer 7A2 $(5.5 \mathrm{ft})$ & n.a. & 40.463 & -78.560 & $\mathrm{~S}$ & P7A-C \\
\hline Piezometer 7B (5.5 ft) & n.a. & 40.463 & -78.560 & $\mathrm{~S}, \mathrm{~L}$ & P7A-C \\
\hline Piezometer 7C (5.5 ft) & n.a. & 40.463 & -78.560 & $\mathrm{~S}$ & P7A-C \\
\hline Piezometer 3A1 (3.5 ft) & n.a. & 40.457 & -78.556 & $\mathrm{~S}, \mathrm{~L}$ & P3A-B \\
\hline Piezometer 3A2 (3.5 ft) & n.a. & 40.457 & -78.556 & $\mathrm{~S}, \mathrm{~L}$ & P3A-B \\
\hline Piezometer 3B (4.5 ft) & n.a. & 40.457 & -78.556 & $\mathrm{~S}, \mathrm{~L}$ & P3A-B \\
\hline
\end{tabular}

${ }^{1}$ Map number identifies sites in figures 1 and 3 .

${ }^{2}$ Piezometer pipes of the same length were not always installed to the same depth. Water level altitude computed as height of water column added to altitude at bottom of pipe.

estimate the distribution of iron redox species prior to other aqueous speciation computations, as described below.

Water-quality samples for laboratory analysis were collected on five different dates (April 2014, and March, June, September, and December 2016) at three sites in the Bradley Run watershed and five sites in the Blair Gap Run watershed, plus once (April 2014) at the AMD discharge on Sugar Run. Samples were filtered $(0.45$-micrometer $[\mathrm{mm}]$ pore size $)$ in the field, transferred to polyethylene bottles, preserved as appropriate, and transported on ice to the laboratory in accordance with standard USGS methods for collection and analysis of water-quality data (U.S. Geological Survey, variously dated).

\section{Analytical Methods}

The acid neutralizing capacity (ANC) was measured on the date of sampling by titrating the chilled samples with $\mathrm{H}_{2} \mathrm{SO}_{4}$ to $\mathrm{pH}$ of 4.5 . The five sets of water samples collected for analysis of major and trace inorganic constituents were shipped to the Actlabs laboratory in Ontario, Canada. Concentrations of dissolved anions (sulfate, chloride, bromide, fluoride, nitrate, nitrite, and phosphate) in filtered, unpreserved subsamples were analyzed by ion chromatography. Concentrations of dissolved silica, major cations (calcium, magnesium, sodium, potassium), and trace elements (lithium, 
strontium, barium, iron, manganese, aluminum, zinc, lead, cobalt, copper, nickel, cadmium, arsenic, selenium, and others) in filtered, acidified subsamples were analyzed by inductively coupled plasma emission mass spectrometry. A total of nine quality assurance and quality control (QAQC) samples was submitted for laboratory analysis including USGS Standard Reference Water samples (SRWS) for major and trace inorganic constituents plus blanks or field blanks. Generally, two QAQC samples were submitted to the laboratory with each set of samples.

Water-quality data and associated hydrologic information for the samples collected during 2014-16 plus the corresponding data for SRWS samples were entered to the USGS National Water Information Storage (NWIS) data base, which can be accessed at http://nwis.waterdata.usgs.gov/pa/nwis/. The water-quality data for the environmental samples and associated QAQC samples are included as appendixes 1-3.

\section{Data-Evaluation and Computational Methods}

The continuously logged stream stage was corrected to the observed staff reading, and then daily average values were computed for comparison with the cumulative daily precipitation data for weather monitoring site PA13 at the ALPO Summit area (National Atmospheric Deposition Program, 2018).

Likewise, the recorded water column height in selected drivepoint piezometers at wetlands 3 and 6 was used to compute the daily average water-level altitude. For evaluation of hydraulic gradients at the two wetlands, the daily average water-level altitudes for shallow piezometers $3 \mathrm{~A} 1$ and $3 \mathrm{~A} 2$ were averaged for comparison to that for deep piezometer $3 \mathrm{~B}$, and those for deep piezometers $6 \mathrm{~A} 1$ and $6 \mathrm{C} 1$ were averaged for comparison to shallow piezometer $6 \mathrm{C} 2$. The daily average of logged water temperature in the same shallow and deep piezometers was also computed. The daily values for data on stream stage and piezometer water-level altitude and water temperature, plus the corresponding daily precipitation and air-temperature data for PA13 that are evaluated in this report can be accessed as digital records from the USGS Science Base at https://doi. org/10.5066/P9YWMMHG.

The $\mathrm{pH}, \mathrm{ANC}$, and dissolved constituent concentrations were used to compute the net acidity, total dissolved solids (TDS), osmotic pressure, and ionic contributions to SPC according to methods reported by Cravotta and Brady (2015). Additionally, because some samples had sodium reported as ">100 milligrams per liter (mg/L)," the sodium concentration required to achieve ionic charge balance was computed and used for computations of TDS and aqueous speciation. The ionic charge balances without the corrected sodium concentrations ranged from -31.0 to 2.9 percent; negative imbalances resulted from incomplete sodium measurements and assuming the concentration reported as $>100 \mathrm{mg} / \mathrm{L}$ was $100 \mathrm{mg} / \mathrm{L}$. The net acidity was computed considering positive acidity contributions by protons $\left(\mathrm{H}^{+}\right.$, indicated by field $\mathrm{pH})$ and dissolved iron, manganese, and aluminum ( $\mathrm{Fe}, \mathrm{Mn}$, and $\mathrm{Al}$ ) concentrations and negative contributions by ANC. The hardness was computed as the sum of concentrations of dissolved calcium $(\mathrm{Ca} \mathrm{mg} / \mathrm{L} \times 2.5)$ and dissolved magnesium $(\mathrm{Mg} \mathrm{mg} / \mathrm{L} \times 4.1)$. The TDS was computed as the sum of major dissolved constituents plus minor constituents, assuming Fe, $\mathrm{Al}$, and $\mathrm{Mn}$ formed hydrous oxides $(\mathrm{FeOOH}, \mathrm{AlOOH}$, and $\mathrm{MnOOH}$, respectively). Finally, the molal concentrations of aqueous species, computed from dissolved concentrations by PHREEQC (Parkhurst and Appelo, 2013), were used to estimate the ionic contributions to SPC (McCleskey and others, 2012) and to estimate the osmotic pressure. The measured SPC compared favorably to computed values of SPC, as shown later.

The measured and computed values for water-chemistry data were evaluated in relation to thresholds for protection of freshwater aquatic organisms. The aquatic thresholds were based on criterion continuous concentration (CCC) values (U.S. Environmental Protection Agency, 2013), which have been adopted by the Commonwealth of Pennsylvania (2001), and (or) in-stream criteria for chemical constituents considered for total maximum daily loads (TMDLs) (Commonwealth of Pennsylvania, 2011a,b; Pennsylvania Department of Environmental Protection, 2016). The criteria for TMDLs generally are consistent with those established to meet the CWF designation of a stream (Commonwealth of Pennsylvania, 2011a):

- temperature during July and August not to exceed $66^{\circ} \mathrm{F}\left(18.9^{\circ} \mathrm{C}\right)$

- dissolved oxygen concentration greater than $5.0 \mathrm{mg} / \mathrm{L}$;

- alkalinity not less than $20 \mathrm{mg} / \mathrm{L}$ as $\mathrm{CaCO}_{3}$, except where natural conditions are less;

- $\mathrm{pH}$ not less than 6.0 or greater than 9.0;

- total iron concentration not to exceed $1.5 \mathrm{mg} / \mathrm{L}$ as a 30-day average;

- dissolved iron concentration not to exceed $0.3 \mathrm{mg} / \mathrm{L}$;

- total manganese concentration not to exceed $1.0 \mathrm{mg} / \mathrm{L}$; and

- total aluminum concentration not to exceed $0.75 \mathrm{mg} / \mathrm{L}$.

Additionally, nutrient water-quality criteria proposed by the U.S. Environmental Protection Agency (2002) for streams, lakes, and reservoirs in Ecoregion XI (Central and Eastern Forested Uplands), which includes the Allegheny Front, could be applicable to minimize nutrient enrichment and eutrophication. The proposed nutrient criteria for total $\mathrm{N}$ and total $\mathrm{P}$ in streams are $0.31 \mathrm{mg} / \mathrm{L}$ and $0.01 \mathrm{mg} / \mathrm{L}$, respectively (U.S. Environmental Protection Agency, 2002). The above thresholds or CCC thresholds were displayed as reference lines on boxplots of constituents to indicate potential for aquatic biological impacts at the monitored sites. 


\section{Hydrologic Characteristics of Headwater Streams and Wetlands}

Instantaneous discharge and stage data were measured by USGS during site visits for comparison with water-quality data and continuous stage measurements. Continuously logged water-level data, recorded at 15-minute intervals at the streamgages and at 1-hour intervals at piezometers, document the range of hydrologic conditions during the study period. Daily average water levels reduce the overall variability and facilitate examination of trends compared to daily rainfall values.

\section{Streamwater Levels and Streamflow}

The stage and discharge measured at each streamgage were positively correlated; increased stage is attributed to increased streamflow. The daily average stage values for the two streamgages, plotted as hydrographs, tracked one another and indicated a rapid response to the cumulative daily precipitation at the local weather station PA13 (National Atmospheric Deposition Program, 2018) (fig. 5). The period of highest peaks and sustained streamflow, during May-July of 2015, was associated with frequent rainfall, whereas the periods of lowest streamflow, during August-September of 2014, 2015, and 2016, were associated with low rainfall combined with high rates of evapotranspiration (fig. 5; table 2). During these low-flow intervals, perennial conditions (water in the channel) were sustained at both gages; however, the streamflow at the Bradley Run gage was severely diminished and recorded as zero flow because flow was transmitted mostly through the streambed (hyporheic flow) between pooled sections and could not be measured using a wading rod and flow meter.

\section{Shallow Subsurface Water Levels}

Differences between the water level altitudes for pairs of piezometers installed to different depths indicate variations in the vertical hydrologic gradients. At wetlands 3 and 6, the continuous water-level records, which were monitored during spring through fall of 2016, demonstrate that the vertical gradient may change in magnitude and direction, from downward or upward, depending on the site and hydrologic conditions (fig. 6).

Wetland 3 (P3A-B in fig. 3), which is in an upland area (altitude 2,370 feet NAVD 88), exhibited a consistent downward gradient (higher water level in shallow piezometer than in deeper piezometer) and potential for local groundwater recharge during rainfall events in the spring through fall seasons (fig. 6). The associated surface seepage at wetland 3 dried up in the summer of 2016.

Wetland 6 (P6A-C in fig. 3), which is in a valley setting (altitude 2,198 feet NAVD 88), exhibited upward hydraulic gradients (groundwater from the deepest piezometer discharged at the surface) in the spring of 2016 (fig. 6), followed

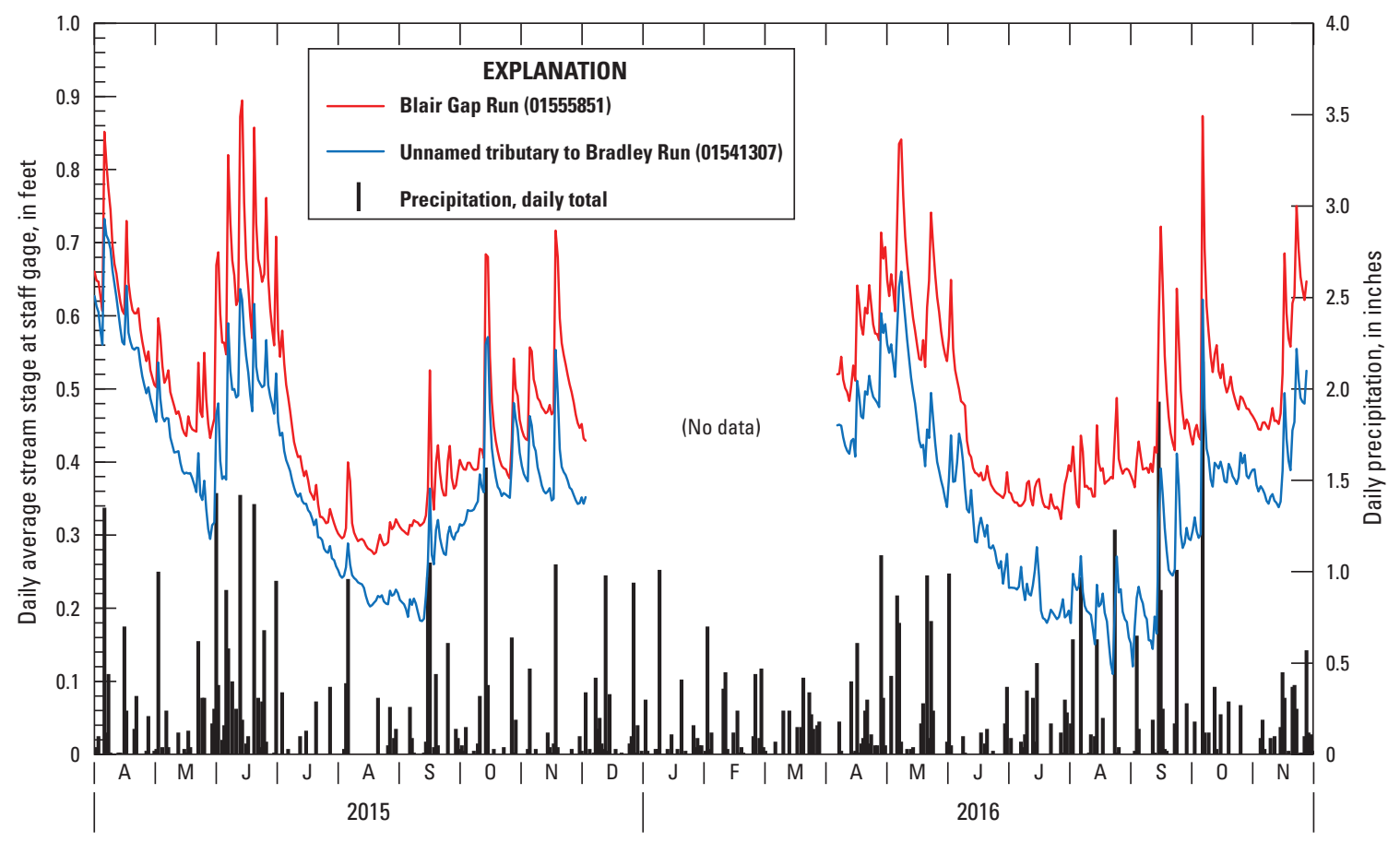

Figure 5. Daily average stream stage at Blair Gap Run (01555851) and unnamed tributary (UNT) to Bradley Run (01541307) compared to cumulative daily precipitation at weather station PA13 (National Atmospheric Deposition Program, 2018) during 2015-16 at the ALPO Summit area, Pennsylvania. Submersible transducers were removed during winter to avoid freezing, resulting in missing data. 
Table 2. Monthly summary of logged-stage unit values at streamgages at the ALPO Summit area, Pennsylvania, May-November, 2015 and 2016. Only months with complete records were included; partial records for April and December of 2015 and 2016 were excluded.

[Month indicated as year and month (yymm); N, number of logged values; values are staff reading in feet above arbitrary datum; UNT, unnamed tributary; blue-shaded cells indicate relatively high-flow conditions and yellow-shaded cells indicate relatively low-flow conditions.]

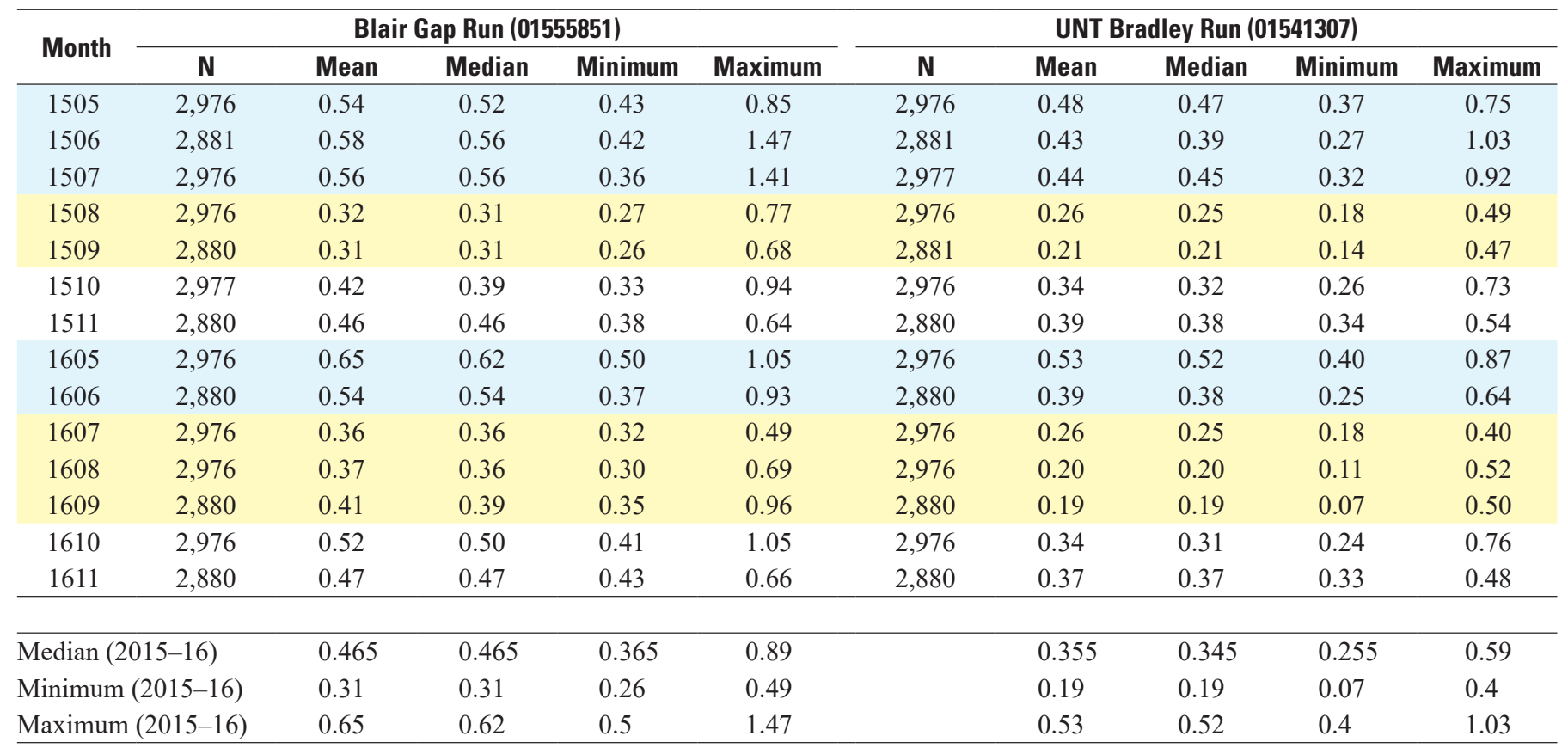

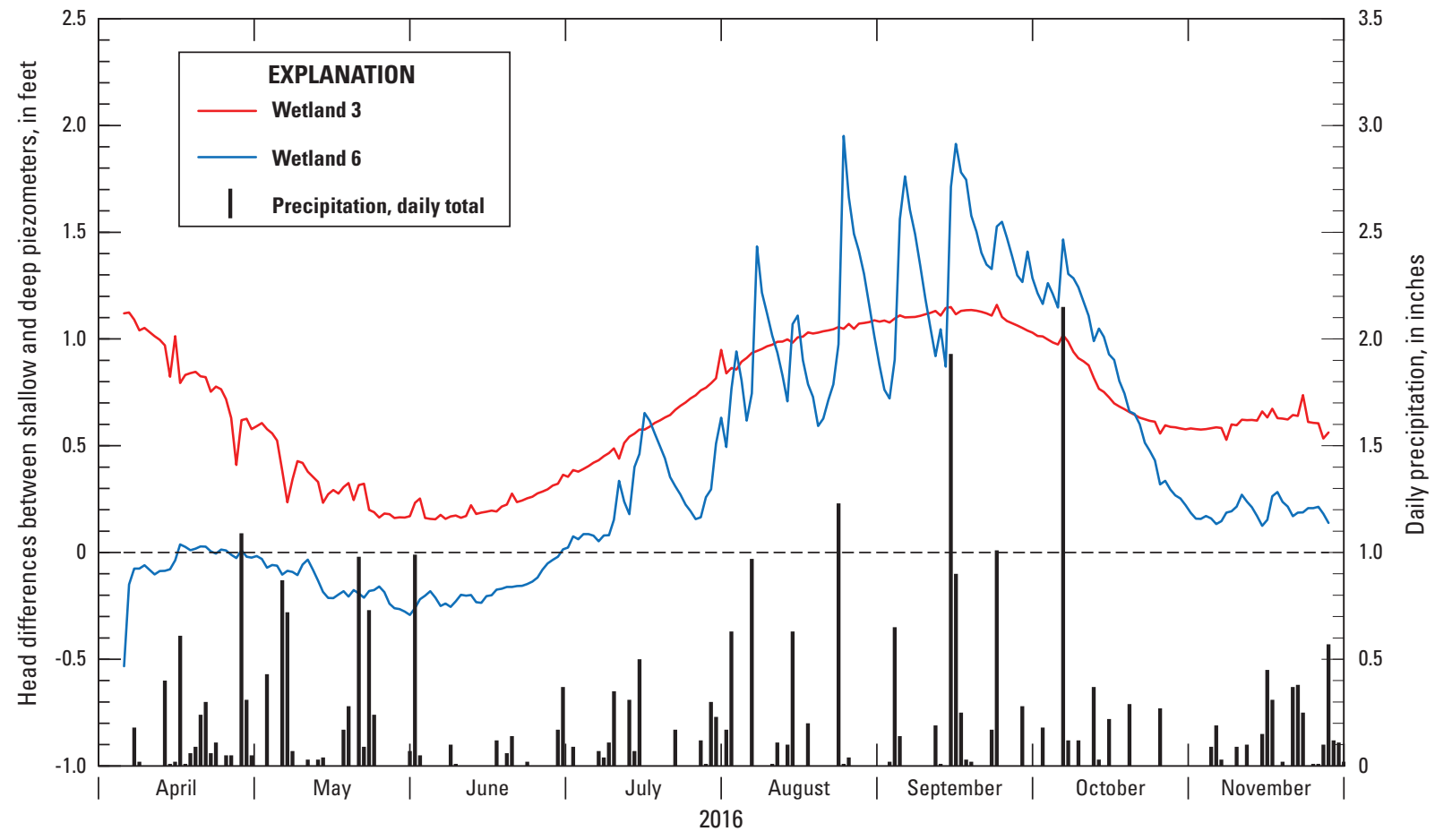

Figure 6. Differences between water-level altitudes in shallow and deep piezometer pairs at wetlands 3 and 6 compared to cumulative daily precipitation at weather station PA13 (National Atmospheric Deposition Program, 2018) during 2016 at the ALPO Summit area, Pennsylvania. A negative value indicates upward gradient. 
by downward gradients in the summer and fall of 2016.

Despite the downward hydraulic gradients, the continuous seepage from wetland 6 sustained perennial conditions in the headwaters of Bradley Run. The large head differences at wetland 6 during summer and fall and increased downward gradient in response to rainfall imply poorly transmissive conditions; recharge entering the shallow zone would tend to move downward, but slowly.

The daily average water temperature in shallow and deep piezometer pairs at wetlands 3 and 6 compared to air temperature is shown in figure 7 . The shallow piezometers had a greater temperature range and responded more rapidly to changes in air temperature than the deep piezometers at each wetland. Despite installation to similar depths, the deep piezometer at wetland 3 achieved greater temperatures in summer than that at wetland 6. The downward flow of water at wetland 3 influenced the water temperature at depth. In contrast, poorly transmissive conditions and limited downward flow at wetland 6 could explain greater differences in temperature between shallow and deep piezometers compared to wetland 3.
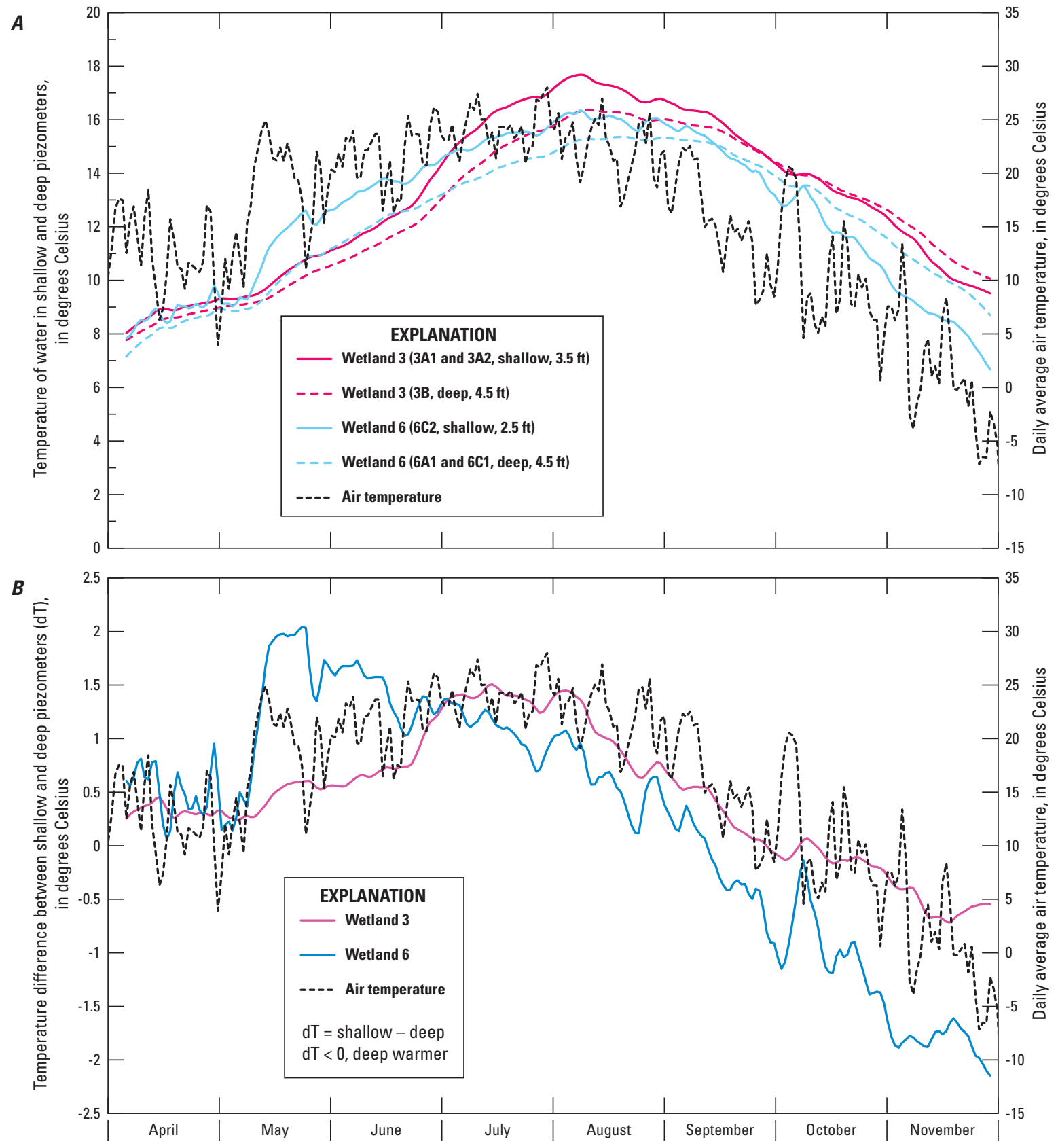

Figure 7. $A$, Daily average water temperature, and, $B$, differences in water temperature (dT) in shallow and deep piezometer pairs at wetlands 3 and 6 compared to daily average air temperature at weather station PA13 (National Atmospheric Deposition Program, 2018) during 2016 at the ALPO Summit area, Pennsylvania. 


\section{Water Quality}

Water-quality and associated hydrologic data were measured for 75 samples collected from 10 sites in 2014-16. A subset of 41 water-quality samples for laboratory analysis was collected at most sites in April 2014, including the Sugar Run AMD, and at all sites except the Sugar Run AMD in March, June, September, and December 2016 (table 1). QAQC samples were analyzed concurrently with these sample sets. The data for environmental samples and associated QAQC samples are stored as digital records in NWIS and are listed in appendixes 1-3, available online at https://doi.org/10.3133/ ofr20181125).

\section{Quality Assurance and Quality Control Results}

The analytical results for QAQC samples indicated that (1) sampling did not introduce contamination in blanks, and (2) concentrations of most constituents reported for the SRWS samples were accurate and precise. The constituent concentrations in two field blanks and one trip blank submitted with environmental samples generally were less than or equal to analytical detection limits and, if detected (chloride, sulfate, sodium, cobalt, zinc), were less than or equal to minimum values reported for the environmental samples (appendixes 1-3). With few exceptions, the results for the three SRWS samples (M194, T201, and T213), including replicate results for M194 and T201, were within an acceptable range of the mostprobable value (MPV) indicated as the median plus or minus two deviations (appendix 3). Thus, the environmental sample results were deemed acceptable for interpretation, except as noted below.

The reported lead concentration value for T213 (16.3 mg/L) analyzed with the March 2016 sample set was substantially greater than its MPV (expected range 2.76 to $3.20 \mathrm{mg} / \mathrm{L}$ ). Likewise, lead concentration values reported for the March 2016 environmental sample set were about 5 times greater than those on other dates. Based on the QAQC results and inconsistency with other sample results, the detected lead concentration values reported for the March 2016 sample set were rejected.

The reported concentrations for bromide and arsenic in environmental samples were scrutinized based on reported values for M194 and T201, respectively, that were higher than MPVs; however, none of the bromide or arsenic data was rejected. Despite poor precision and accuracy for bromide concentrations for M194 (appendix 3), all but one environmental sample had a reported bromide concentration less than detection. The only environmental sample with a detected bromide concentration $(0.18 \mathrm{mg} / \mathrm{L})$ was analyzed in March 2016 concurrent with M194 whose reported bromide concentration of $0.25 \mathrm{mg} / \mathrm{L}$ was greater than its MPV ( 0.04 to $0.10 \mathrm{mg} / \mathrm{L})$. The environmental sample with a detected bromide concentration
(Skew Arch Bridge) had consistently high concentrations of chloride and sulfate (table 1 and appendix 2) and, consequently, was diluted for anion analysis to greater extent than samples from other sites. Other samples from Skew Arch Bridge had bromide concentrations below detection $(<0.1$ to $<0.3 \mathrm{mg} / \mathrm{L}$ ); the value of $0.18 \mathrm{mg} / \mathrm{L}$ was consistent with this censored data range. The arsenic data values reported for T201 were comparable to one another ( 23.2 and $28.8 \mathrm{mg} / \mathrm{L}$ ) and the MPV (21.3 to $27.5 \mathrm{mg} / \mathrm{L}$ ); however, the value of $28.8 \mathrm{mg} / \mathrm{L}$, reported for September 2016, was slightly greater than the MPV. Although the environmental sample results for arsenic on September 2016 were among the highest reported, they could be attributed to extreme low-flow conditions with elevated dissolved solids.

\section{Water Quality Characteristics Compared to Criteria for Protection of Aquatic Life}

The median and range for the environmental samples submitted for laboratory analysis are summarized by site in table 3, available online at https://doi.org/10.3133/ ofr20181125. Values are reported for 77 constituents including 5 calculated parameters. The calculated parameters are sodium (to achieve charge balance), net acidity, hardness, TDS, and osmotic pressure. The data for these calculated parameters and selected major and trace inorganic constituents also are displayed as boxplots (fig. 8).

Although the stream water in both Blair Gap Run and Bradley Run met the CWF criteria for temperature and DO during 2014-16, the samples from Blair Gap Run and its tributaries at the Summit area had greater concentrations of most major and trace elements than the tributaries of Bradley Run (fig. 8).

At the streamgage, Blair Gap Run had $\mathrm{pH}$ that ranged from 5.2 to 7.2 with variable net acidity and elevated SPC (240-308 microsiemens per centimeter $[\mu \mathrm{S} / \mathrm{cm}])$ (table 3 , fig. 8). The elevated SPC is correlated with TDS and other measures of ionic strength, and can be attributed mainly to concentrations of sulfate, chloride, and sodium, as explained in more detail below. The south fork of Blair Gap Run, which was the predominant source of streamflow to Blair Gap Run at the gage, had $\mathrm{pH}$ as low as 4.5 , median net acidity greater than 0 , sulfate concentrations as high as $150 \mathrm{mg} / \mathrm{L}$, and moderately elevated concentrations of aluminum, iron, and manganese. Additionally, Blair Gap Run or one of its tributaries had several trace metal exceedances (nickel, zinc, and cadmium) (fig. 8, table 3). Although these characteristics are indicative of AMD, discharges from mine adits or tunnels were not otherwise apparent. The north fork of Blair Gap Run had consistently near-neutral $\mathrm{pH}$ with negative net acidity (net alkaline) and low to moderate concentrations of sulfate (less than $60 \mathrm{mg} / \mathrm{L}$ ); however, this tributary had substantially elevated SPC and chloride concentrations, which indicate probable effects from road de-icing salt. The chloride concentrations in 

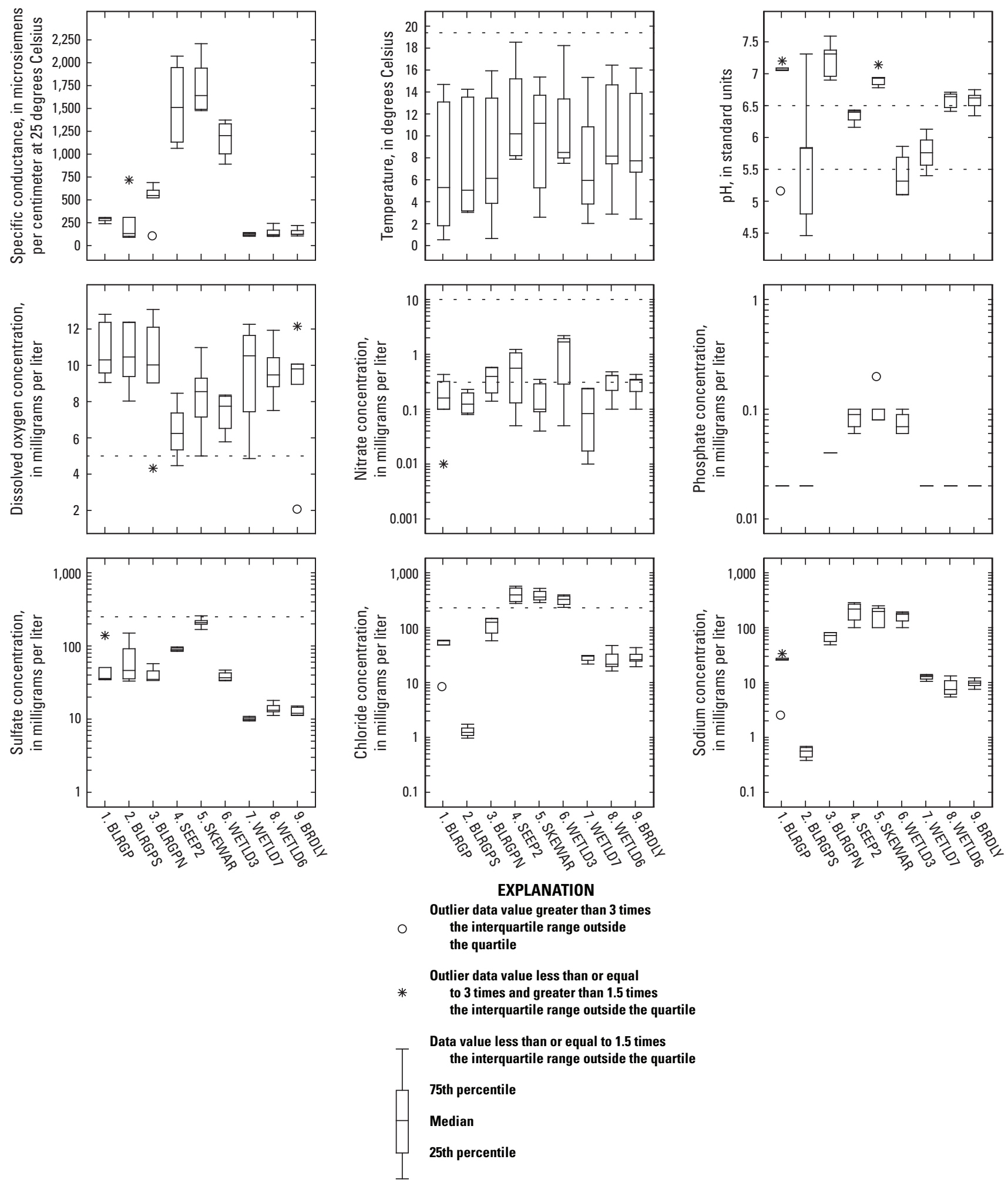

Figure 8. Selected constituent concentrations and criterion-continuous concentration (CCC) thresholds (shown with dashed lines) for protection of freshwater aquatic life at water-quality monitoring sites, ALPO Summit area, Pennsylvania. Symbols and units of measure for constituents are indicated in table 3. Site names are abbreviated with map number prefix (table 1, fig. 3) as follows: 1. BLRGP, Blair Gap Run; 2. BLRGPS, Blair Gap Run south fork; 3. BLRGPN, Blair Gap Run north fork; 4. SEEP2, seep 2; 5. SKEWAR, Skew Arch Bridge seepage; 6. WETLD3, wetland 3; 7. WETLD7, wetland 7; 8. WETLD6, wetland 6; and 9. BRDLY, Unnamed tributary to Bradley Run. 

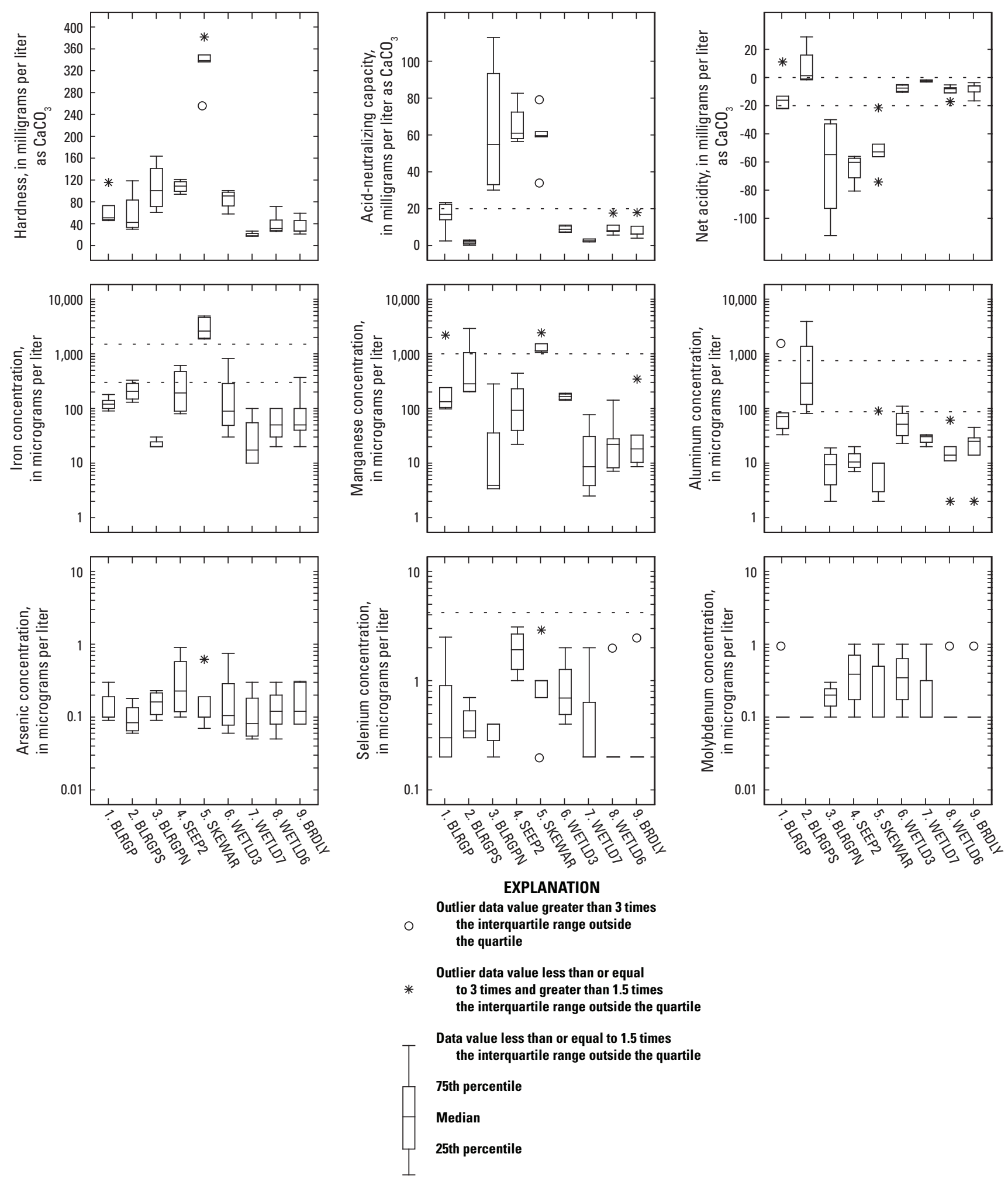

Figure 8. Selected constituent concentrations and criterion-continuous concentration (CCC) thresholds (shown with dashed lines) for protection of freshwater aquatic life at water-quality monitoring sites, ALPO Summit area, Pennsylvania. Symbols and units of measure for constituents are indicated in table 3. Site names are abbreviated with map number prefix (table 1, fig. 3) as follows: 1. BLRGP, Blair Gap Run; 2. BLRGPS, Blair Gap Run south fork; 3. BLRGPN, Blair Gap Run north fork; 4. SEEP2, seep 2; 5. SKEWAR, Skew Arch Bridge seepage; 6. WETLD3, wetland 3; 7. WETLD7, wetland 7; 8. WETLD6, wetland 6; and 9. BRDLY, Unnamed tributary to Bradley Run.-Continued 

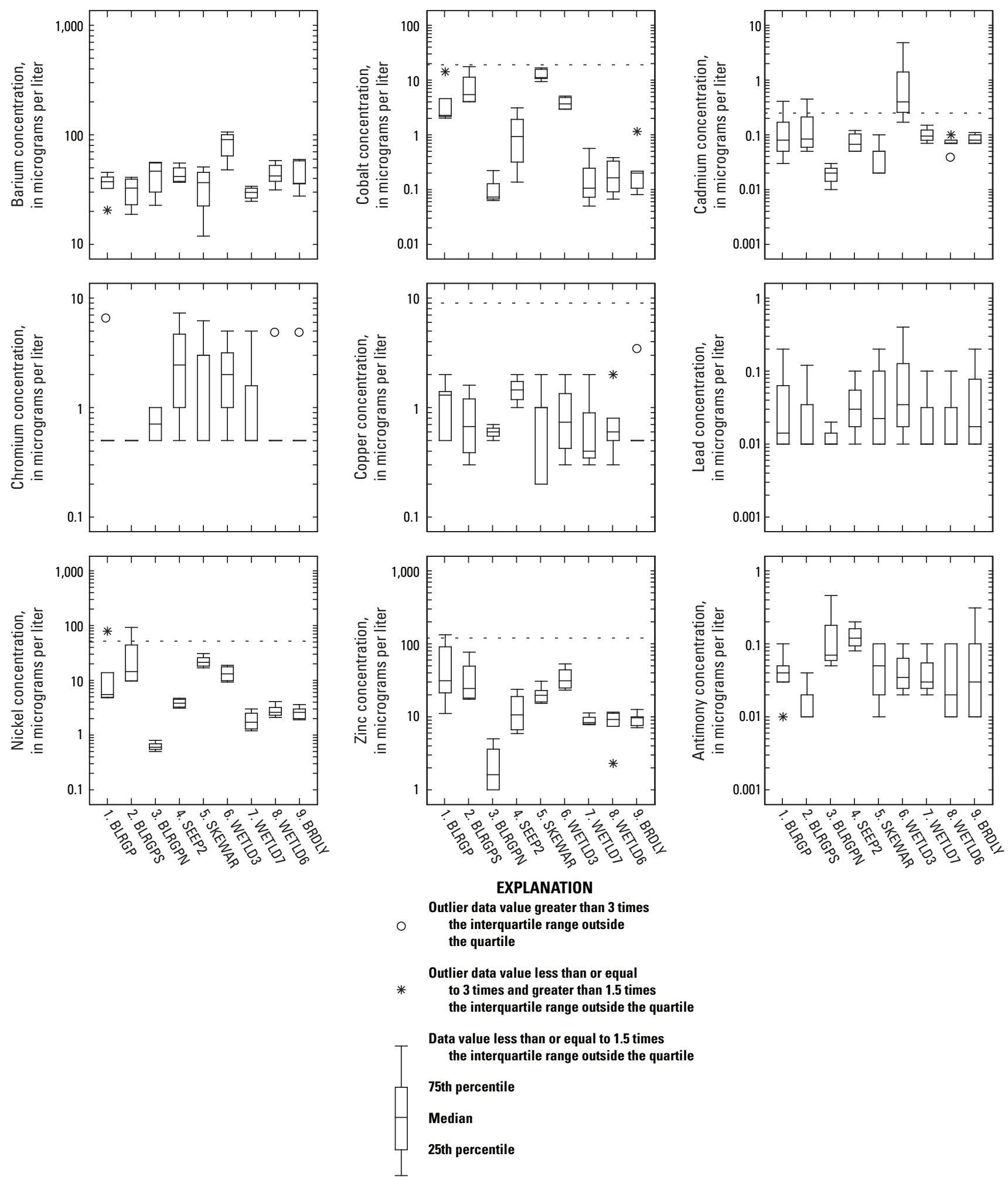

Figure 8. Selected constituent concentrations and criterion-continuous concentration (CCC) thresholds (shown with dashed lines) for protection of freshwater aquatic life at water-quality monitoring sites, ALPO Summit area, Pennsylvania. Symbols and units of measure for constituents are indicated in table 3. Site names are abbreviated with map number prefix (table 1, fig. 3) as follows: 1. BLRGP, Blair Gap Run; 2. BLRGPS, Blair Gap Run south fork; 3. BLRGPN, Blair Gap Run north fork; 4. SEEP2, seep 2; 5. SKEWAR, Skew Arch Bridge seepage; 6. WETLD3, wetland 3; 7. WETLD7, wetland 7; 8. WETLD6, wetland 6; and 9. BRDLY, Unnamed tributary to Bradley Run.-Continued 
seep 2, which is near Admiral Peary Highway/Old Route 22 and contributes flow to the north fork of Blair Gap Run, exceeded the CCC threshold for chloride (fig. 8). Likewise, the seepage from Skew Arch Bridge and wetland 3, which are also near Admiral Peary Highway/Old Route 22, had elevated chloride.

The water quality at the streamgage on the unnamed tributary of Bradley Run, downstream of wetlands 6 and 7, was characterized by near-neutral $\mathrm{pH}$ and relatively low SPC and associated concentrations of dissolved constituents. The streamwater and associated wetland seepage generally met thresholds for protection of freshwater aquatic life. However, water samples of both Bradley Run and Blair Gap Run had nitrate concentrations that were sometimes elevated in comparison to the nutrient criterion threshold of $0.31 \mathrm{mg} / \mathrm{L}$ as nitrogen for regional streams.

By comparison, the deep groundwater from the underlying Argyle Stone Bridge Mine, at its Sugar Run discharge
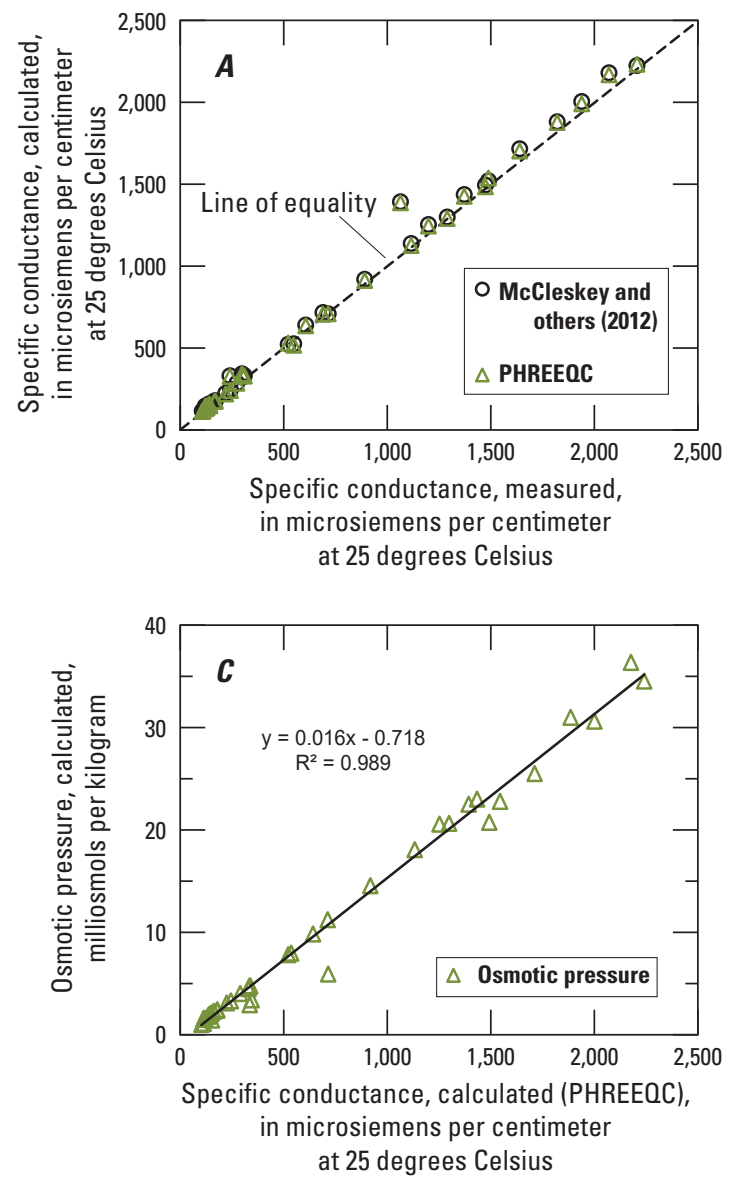

north of the Summit area, had pH of 3.5 and elevated concentrations of sulfate $(270 \mathrm{mg} / \mathrm{L})$, aluminum, manganese, iron, and other trace metals, including cobalt, nickel, copper, zinc, and cadmium in April 2014 (table 3). The metals concentrations in this AMD sample exceeded CCC thresholds for aquatic life. However, the concentrations of chloride $(20.2 \mathrm{mg} / \mathrm{L})$ and nitrate $(<0.05 \mathrm{mg} / \mathrm{L}$ as nitrogen $)$ were relatively low.

\section{Ionic Contributions to Specific Conductance and Other Measures of Ionic Strength}

The measured SPC is comparable to that computed from ionic contributions by methods of McCleskey and others (2012) and by PHREEQC using methods of Appelo and others (2010) (fig. 9). Also, the SPC is proportional to other measures of overall salinity including the TDS, osmotic pressure,
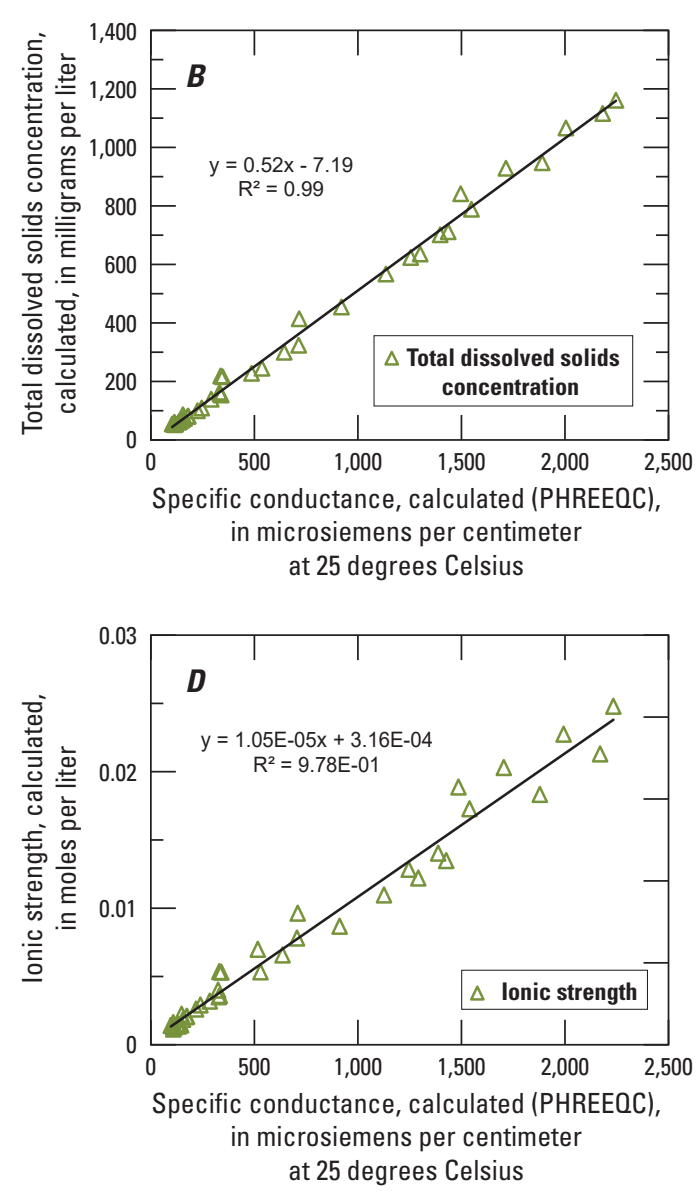

Figure 9. Comparison of measured and calculated (calc) values of specific conductance (SPC), total dissolved solids (TDS), osmotic pressure, and ionic strength for 41 water samples from ALPO Summit area monitoring sites, 2014-16: A, SPC calculated from ionic composition by two different methods compared to measured SPC; B, TDS calculated as the sum of dissolved constituent concentrations compared to calculated SPC; C, calculated osmotic pressure and SPC on the basis of dissolved constituent concentrations; and D, calculated ionic strength and SPC on the basis of dissolved constituent concentrations. 
and ionic strength, as shown in figure 9. Cravotta and Brady (2015) discuss the relations among these salinity measures in the context of regulatory criteria.

The ionic contributions to SPC of the water samples from the Blair Gap Run and Bradley Run streams and tributaries were from the species, $\mathrm{Cl}^{-}, \mathrm{SO}_{4}^{2-}, \mathrm{HCO}_{3}^{-}, \mathrm{Na}^{+}, \mathrm{Ca}^{2+}$, and $\mathrm{Mg}^{2+}$ (fig. 10). In contrast, the ionic contributions to SPC of the Sugar Run AMD were mainly from $\mathrm{SO}_{4}{ }^{2-}, \mathrm{Ca}^{2+}, \mathrm{Mg}^{2+}$, $\mathrm{H}^{+}$, and, to a lesser extent, $\mathrm{Cl}^{-}, \mathrm{Na}^{+}, \mathrm{K}^{+}, \mathrm{Fe}^{2+}, \mathrm{Mn}^{2+}$, and $\mathrm{Al}^{3+}$. Because of contributions of different ions to the SPC, waters having the same SPC value could have significantly different chemical and toxicological characteristics. For example, the north fork of Blair Gap Run and the Sugar Run AMD have similar SPC values of 717 and $709 \mu \mathrm{S} / \mathrm{cm}$, respectively, but very different ionic composition (fig. 10B). Thus, elevated SPC values generally indicate contamination; however, supplemental measurements, such as $\mathrm{pH}$ and dissolved concentrations of chloride, sulfate, iron, and other metals are helpful to identify the source(s) of contaminants and potential effects to aquatic life.

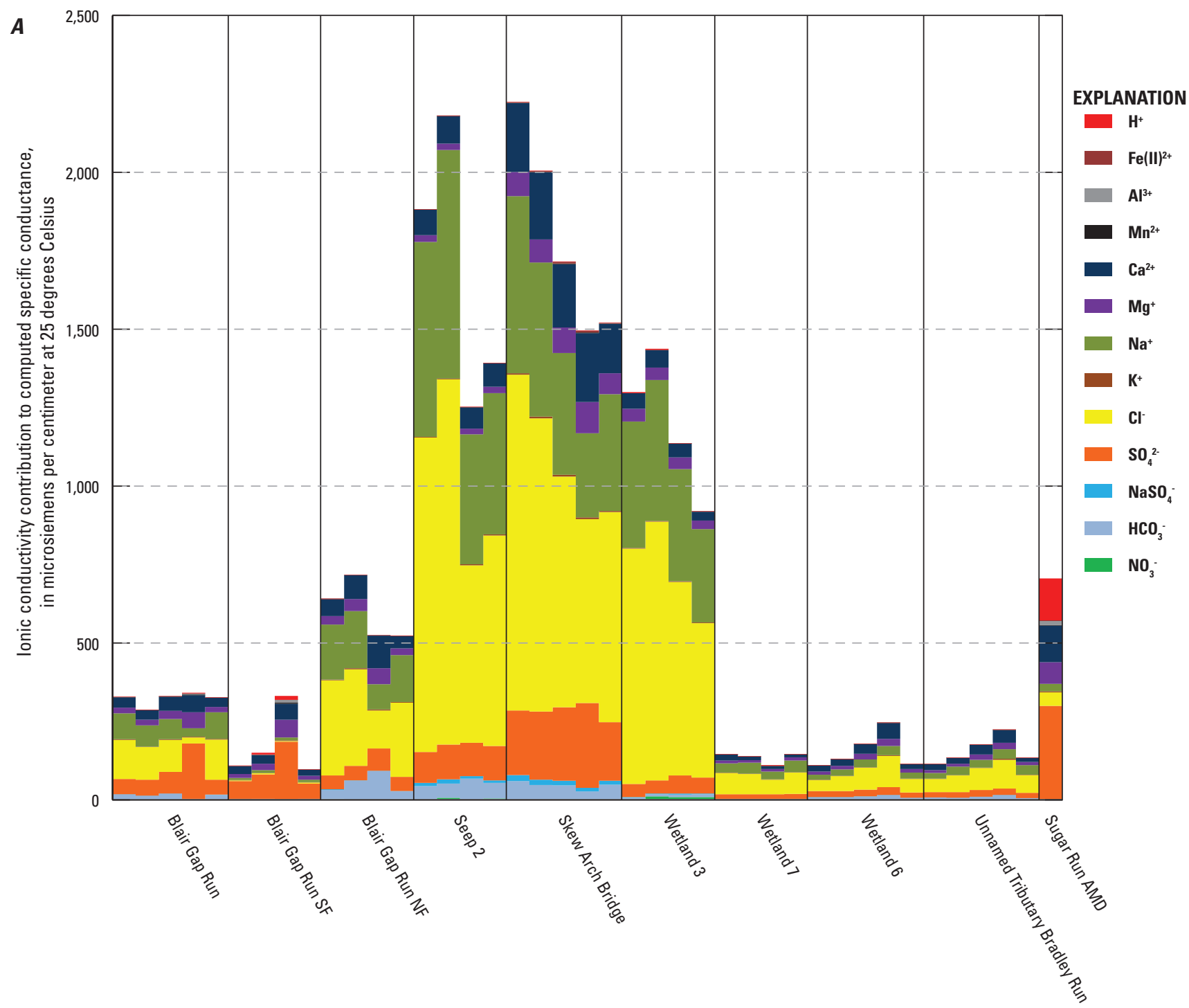

Figure 10. Major ion contributions to specific conductance (SPC) for water samples from ALPO Summit area, 2014-16: $A$, ionic conductivity contributions to specific conductance of samples collected at ALPO monitoring sites in 2014-16 (each bar is a different sample at a site), and $B$, average contributions by major ion species to computed SPC, expressed in percent, June 2016. Individual ion conductivities estimated from dissolved constituent concentrations as the transport number (relative contribution of a given ion to the overall conductivity, using the methods of McCleskey and others, 2012) after aqueous speciation calculations with PHREEOC (Parkhurst and Appelo, 2013). (\%, percent; $\mu \mathrm{S} / \mathrm{cm}$ at $25{ }^{\circ} \mathrm{C}$, microsiemens at 25 degrees Celsius; AMD, acid mine drainage) 
B

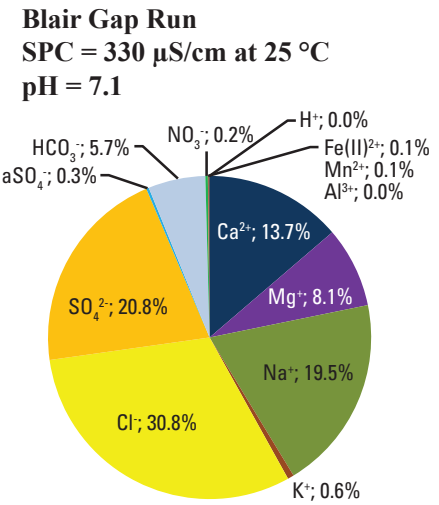

Skew Arch Bridge

$\mathrm{SPC}=1,718 \mu \mathrm{S} / \mathrm{cm}$ at $25^{\circ} \mathrm{C}$ $\mathrm{pH}=6.9$

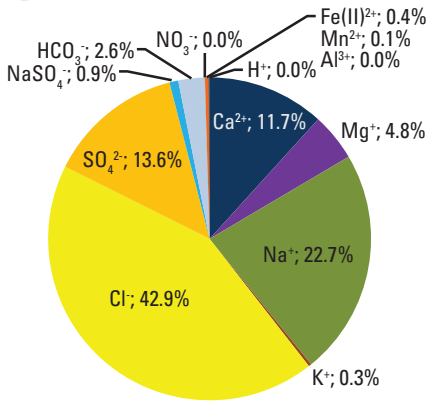

Wetland 6

$\mathrm{SPC}=178 \mu \mathrm{S} / \mathrm{cm}$ at $25^{\circ} \mathrm{C}$

$\mathrm{pH}=6.6$

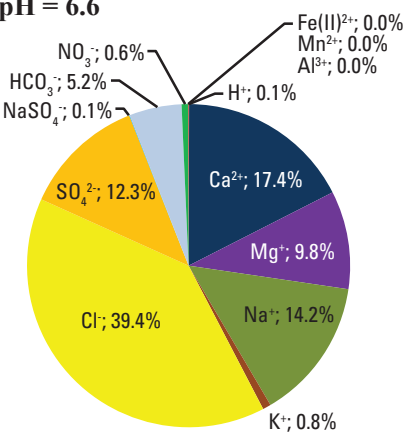

Blair Gap Run South Fork

$\mathrm{SPC}=151 \mu \mathrm{S} / \mathrm{cm}$ at $25^{\circ} \mathrm{C}$

$\mathrm{pH}=4.8$

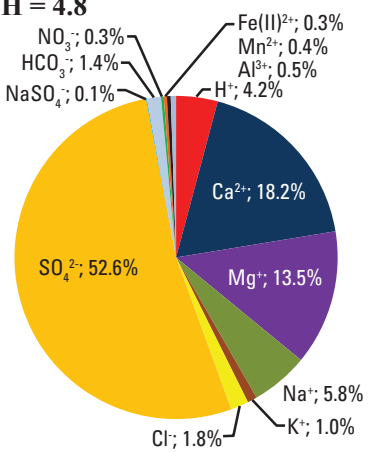

Wetland 3

$\mathrm{SPC}=1,138 \mu \mathrm{S} / \mathrm{cm}$ at $25^{\circ} \mathrm{C}$

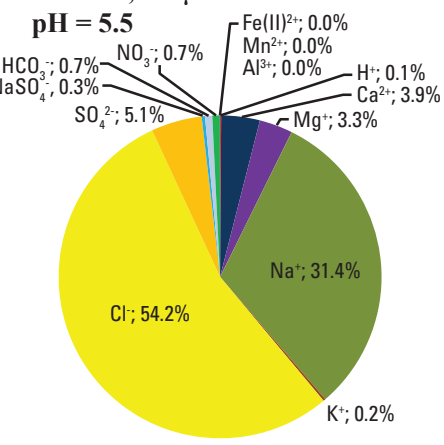

Unnamed tributary Bradley Run

$\mathrm{SPC}=176 \mu \mathrm{S} / \mathrm{cm}$ at $25^{\circ} \mathrm{C}$

$\mathrm{pH}=6.6$

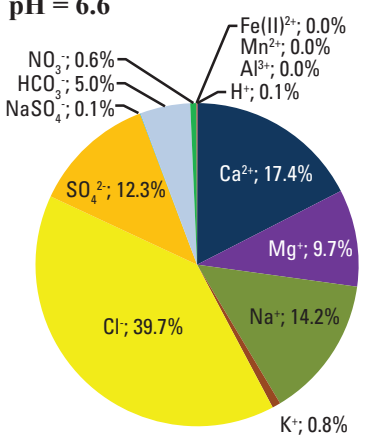

EXPLANATION

Major ion species

$\begin{array}{lll}\mathrm{H}^{+} & \mathrm{Cl}^{-} & \mathrm{Fe}(\mathrm{II})^{2+} \\ \mathrm{Ca}^{2+} & \mathrm{SO}_{4}{ }^{2 \cdot} & \mathrm{Mn}^{2+} \\ \mathrm{Mg}^{+} & \mathrm{NaSO}_{4}{ }^{-} & \mathrm{Al}^{3+} \\ \mathrm{Na}^{+} & \mathrm{HCO}_{3}{ }^{-} & \\ \mathrm{K}^{+} & \mathrm{NO}_{3}{ }^{-} & \end{array}$

Blair Gap Run North Fork $\mathrm{SPC}=717 \mu \mathrm{S} / \mathrm{cm}$ at $25^{\circ} \mathrm{C}$

$\mathrm{pH}=7.6$

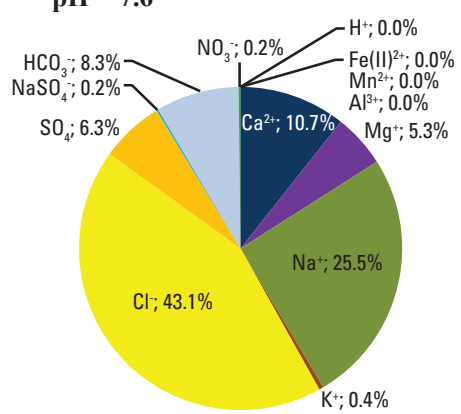

Wetland 7

$\mathrm{SPC}=110 \mu \mathrm{S} / \mathrm{cm}$ at $25^{\circ} \mathrm{C}$

$\mathrm{pH}=\mathbf{5 . 4}$

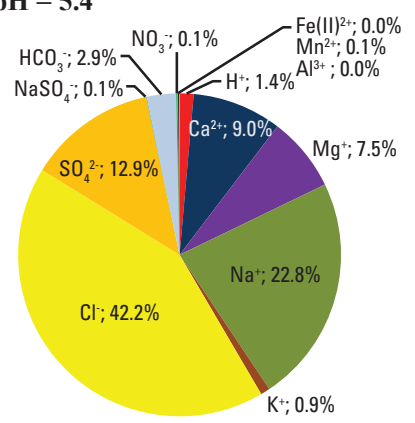

Sugar Run Acid-Mine Drainage

$\mathrm{SPC}=709 \mu \mathrm{S} / \mathrm{cm}$ at $25^{\circ} \mathrm{C}$

$\mathrm{pH}=3.5$

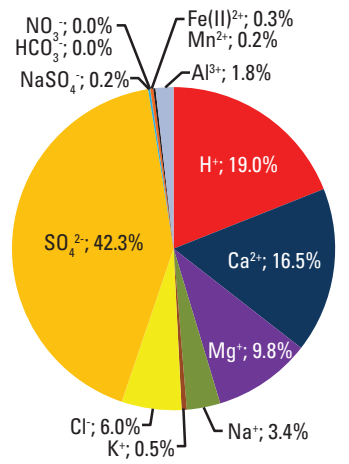

Figure 10. Major ion contributions to specific conductance (SPC) for water samples from ALPO Summit area, 2014-16: A, ionic conductivity contributions to specific conductance of samples collected at ALPO monitoring sites in 2014-16 (each bar is a different sample at a site), and $B$, average contributions by major ion species to computed SPC, expressed in percent, June 2016. Individual ion conductivities estimated from dissolved constituent concentrations as the transport number (relative contribution of a given ion to the overall conductivity, using the methods of McCleskey and others, 2012) after aqueous speciation calculations with PHREEOC (Parkhurst and Appelo, 2013). (\%, percent; $\mu \mathrm{S} / \mathrm{cm}$ at $25^{\circ} \mathrm{C}$, microsiemens at 25 degrees Celsius; AMD, acid mine discharge)—Continued 


\section{Summary and Conclusions}

Surface-water resources in the ALPO Summit area consist of headwater streams, seeps, and wetlands, plus some associated intermittent seeps in the Blair Gap Run and Bradley Run watersheds in the eastern and western parts of the area, respectively. During 2014-16, streamflow and stream stage at gages installed by the USGS on Blair Gap Run and the unnamed tributary of Bradley Run exhibited typical variations in response to rainfall, snowmelt, and dry periods. Both streams remained perennial during dry conditions, with water mainly in pools, reaching the point of zero flow in AugustSeptember of 2014, 2015, and 2016. During these conditions, hyporheic flow through the streambed between pools was apparent but was not quantified.

During 2016, drive-point piezometers documented shallow groundwater levels, ranging from the surface to depths of 4 to 5 feet, at wetlands upstream of the streamgages on Blair Gap Run and the unnamed tributary of Bradley Run. Downward gradients (decreased water-level altitude with depth) at wetlands in both watersheds were indicative of potential for surface water losses to the subsurface during the late summer and fall. In contrast, upward hydraulic gradients in the spring to early summer period were indicative of the potential for groundwater discharge at wetland 6 , in the headwaters of Bradley Run. The groundwater discharge was apparent as artesian flow from only the deeper piezometers; the water level always remained below ground level at the adjacent shallow piezometer.

Blair Gap Run and associated tributaries, seeps, and wetlands exhibited poor water quality during 2014-16. Elevated SPC and associated concentrations of dissolved ions including sodium, chloride, sulfate, iron, manganese, zinc, and other dissolved metals in the water samples collected for this investigation are consistent with contamination by road deicing salts and abandoned coal mine drainage. Winter application of road salt on Admiral Peary Highway/Old Route 22, which parallels Blair Gap Run, is the probable source of elevated chloride and sodium. Although discharges from mine adits or tunnels were not apparent, the coal mine drainage could originate as seepage from spoil and shallow mine workings within the Upper Freeport (E) coal bed, which was extensively mined beneath the ALPO Summit area and crops out in the vicinity of the streamgage on Blair Gap Run.

The unnamed tributary to Bradley Run and associated wetlands and seeps, exhibited only minor effects, if any, from road-deicing salts and did not exhibit water-quality effects from AMD. These water resources were characterized by relatively low SPC and near-neutral $\mathrm{pH}$. In contrast, the Sugar Run AMD, which discharges from the Argyle Stone Bridge Mine in the Lower Kittanning (B) coal bed had elevated SPC and acidic $\mathrm{pH}$.

Spatial separation combined with differences in groundwater altitudes and associated water quality among the surface water, shallow groundwater, and deep groundwater in the
Summit area imply that the surface water and shallow groundwater in the study area could recharge the deeper groundwater of the underlying coal mines but the shallow groundwater and associated surface water are not directly affected by AMD from the underlying Argyle Stone Bridge Mine. Seasonally upward and downward vertical gradients in the near-surface soil and bedrock at wetland 6 and unimpaired water quality in the Bradley Run headwaters are consistent with a perched water table and local hydrology that is influenced by local recharge. Persistent downward gradients and impaired water quality at wetland 3 and the adjacent headwaters seeps and tributaries of Blair Gap Run could be attributed to subsidence and drainage associated with shallow coalbeds and mine workings in that area. Road-deicing salts and associated runoff and recharge also add contaminants to the headwaters of Blair Gap Run.

The $\mathrm{pH}$ and SPC of water samples are generally simple to measure in the field and can indicate potential contamination; however, additional information on the chemical composition is needed to distinguish between neutralized AMD, road deicing salt, and other possible sources of contaminants. Major ion concentrations indicate two main sources of contamination in the Blair Gap Run watershed are road-deicing salt from the Admiral Peary Highway/Old Route 22 and abandoned coalmine seepage from mine adits or runoff from spoils upstream of monitoring sites. These sources of salinity, indicated by elevated TDS, SPC, and osmotic pressure, directly affect the freshwater aquatic characteristics and influence the trace element mobility and toxicity in the headwaters and, possibly, downstream reaches.

\section{Acknowledgments}

Matthew Conlon and Heather L. Eggleston of U.S. Geological Survey assisted with data collection and processing. Funds for the field work and associated data evaluation and reporting by USGS were provided by the National Park Service Natural Resource Preservation Program (NRPP).

\section{References Cited}

Appelo, C.A.J., Van Loon, L.R., and Wersin, P., 2010, Multicomponent diffusion of a suite of tracers ( $\mathrm{HTO}, \mathrm{Cl}, \mathrm{Br}$, I, $\mathrm{Na}, \mathrm{Sr}, \mathrm{Cs}$ ) in a single sample of Opalinus Clay: Geochimica et Cosmochimica Acta, v. 74, p. 1201-1219.

Cloues, P., 1992, Allegheny Portage Railroad National Historic Site abandoned coal mine subsidence analysis: Unpublished report, National Park Service, Land Resources Division, Mining and Minerals Branch, October 13, 1992, $22 \mathrm{p}$. 
Commonwealth of Pennsylvania, 2001, Chapter 16. Water quality toxics management strategy-Statement of policy: Pennsylvania Code, Title 25. Environmental protection, 25 Pa. Code $\S 16$, , p. 16.1-16.46.

Commonwealth of Pennsylvania, 2011a, Chapter 93. Water quality standards: Pennsylvania Code, Title 25. Environmental protection, $25 \mathrm{~Pa}$. Code $\S 93$.

Commonwealth of Pennsylvania, 2011b, Policy and procedure for NPDES permitting of discharges of total dissolved solids (TDS). Chapter 93. Water quality standards: Pennsylvania Code, Title 25. Environmental protection, $25 \mathrm{~Pa}$. Code $\$ 95.10$.

Cravotta, C.A., III, 2005, Assessment of characteristics and remedial alternatives for abandoned mine drainage - Case study at Staple Bend Tunnel Unit of Allegheny Portage Railroad National Historic Site, Cambria County, Pennsylvania, 2004: U.S. Geological Survey Open-File Report 2005-1283, 52 p.

Cravotta, C.A., III, and Brady, K.B.C., 2015, Priority pollutants in untreated and treated discharges from coal mines in Pennsylvania, U.S.A.: Applied Geochemistry, v. 62, p. $108-130$.

Cravotta III, C.A., Galeone, D.G., Penrod, K.A., and Conlon, M.D., 2018, Hydrologic data collected by the U.S. Geological Survey and National Park Service at the Allegheny Portage Railroad National Historic Site, Summit Area, Blair and Cambria Counties, Pennsylvania, April 2014-December 2016: U.S. Geological Survey data release, https://doi. org/10.5066/P9YWMMHG.

Glover, A.D., 1990, Coal resources of Cambria and Blair Counties, Pennsylvania. Part 1. Coal crop lines, mined- out areas, and structure contours: Pennsylvania Geological Survey, 4th ser., Mineral Resource Report 96.

McCleskey, R.B, Nordstrom, D.K., Ryan, J.N., and Ball, J.W., 2012, A new method of calculating electrical conductivity with applications to natural waters: Geochimica et Cosmochimica Acta, v. 77, p. 369-382.

National Atmospheric Deposition Program, 2018, Daily precipitation data at PA13 for 2014-2017 (ver. 2.0, June 13, 2008): National Atmospheric Deposition Program web page, accessed February 8, 2018, at http://nadp.slh.wisc. edu/siteOps/ppt/default.aspx.

National Park Service, 2014, Allegheny Portage Railroad National Historic Site tract and boundary data: National Park Service Integrated Resource Manager Applications Portal web page, accessed April 30, 2018, at https://irma. nps.gov/DataStore/Reference/Profile/2215968.
National Park Service, 2016, Allegheny Portage Railroad National Historic Site Pennsylvania - History and Culture: National Park Service web page, accessed April 18, 2018, at https://www.nps.gov/alpo/learn/historyculture/index.htm.

Nordstrom, D.K., 1977, Thermochemical redox equilibria of ZoBell's solution: Geochimica et Cosmochimica Acta, v. 41 , p. $1835-1841$.

P-STAT, Inc., 2008, An introductory guide for P-STAT Windows users: Princeton, New Jersey, P-STAT, Inc.

Parkhurst, D.L., and Appelo, C.A.J., 2013, Description of input and examples for PHREEQC version 3-A computer program for speciation, batch-reaction, one-dimensional transport, and inverse geochemical calculations: U.S. Geological Survey Techniques and Methods, book 6, chap. A43, $497 \mathrm{p}$.

Pennsylvania Department of Conservation and Natural Resources, 2001, Bedrock geology of Pennsylvania: Pennsylvania Department of Conservation and Natural Resources web page, accessed February 8, 2018, at http://www.denr.state.pa.us/cs/groups/public/documents/ document/denr_015962.zip.

Pennsylvania Department of Conservation and Natural Resources, 2015a, LIDAR data for Blair County, Pennsylvania: PASDA web page, accessed February 8, 2018, at ftp://ftp.pasda.psu.edu/pub/pasda/pamap/pamap_lidar/ cycle1/DEM_mosaics/PAMAP_DEM_mosaic_Blair_1m. zip.

Pennsylvania Department of Conservation and Natural Resources, 2015b, LIDAR data for Cambria County, Pennsylvania: PASDA web page, accessed February 8, 2018, at ftp://ftp.pasda.psu.edu/pub/ pasda/pamap/pamap_lidar/cycle1/DEM_mosaics/ PAMAP_DEM_mosaic_Cambria_1m.zip.

Pennsylvania Department of Environmental Protection, 2015, Environmental assessment Cresson AMD Treatment Plant, Cambria and Blair Counties, Pennsylvania: National Park Service web page, accessed February 8, 2018, at https://parkplanning.nps.gov/ showFile.cfm?projectID $=51622 \&$ MIMEType $=$ app lication $\% 252$ Fpdf\&filename $=$ Cresson $\% 20 \mathrm{EA} \% 20$ $1 \% 2$ Epdf\&sfid=222226. 
Pennsylvania Department of Environmental Protection, 2016, Triennial review of water quality standards-Rationale for the development of ambient water quality criteria for chloride protection of aquatic life: Pennsylvania Department of Environmental Protection, Bureau of Clean Water, 9 p., accessed February 8, 2018, at http://files.dep.state. pa.us/PublicParticipation/Public\%20Participation $\% 20$ Center/PubPartCenterPortalFiles/Environmental\%20

Quality\%20Board/2016/September\%2020/Triennial\%20

Review/08_7-534_Triennial\%202016_Chloride $\% 20$ Rationale.pdf.

Pennsylvania State University, 2014, Pennsylvania Mine Map Atlas, accessed February 8, 2018, at http://www.minemaps. psu.edu/?LocalSheetId=0827_UMM_400_001.

Sharpe, P., Norris, M., and Forget, A., 2012, Wetland and waterway report for travel, Allegheny Portage Railroad National Historical Park (sic) (Summit area), September 17-20, 2012: National Park Service Memorandum dated October 26, 2012, to Dr. Kathy Penrod, Natural Resources Specialist, $12 \mathrm{p}$.

Sheeder, S.A., and Tzilkowski, C.J., 2006, Level I water quality inventory and aquatic biological assessment of the Allegheny Portage Railroad National Historic Site and the Johnstown Flood National Memorial: National Park Service, Technical Report NPS/NER/NRTR-2006/060, 92 p.

Tzilkowski, C.J., Weber, A.S., Callahan, K.K., and Marshall, M.R., 2011, Wadeable stream monitoring in Allegheny Portage Railroad National Historic Site, Delaware Water Gap National Recreation Area, Johnstown Flood National Memorial, and Upper Delaware Scenic and Recreational River; Eastern Rivers and Mountains Network: National Park Service, Natural Resource Data Series NPS/ERMN/ NRDS-2011/212, 32 p.

U.S. Environmental Protection Agency, 2002, Summary table for the nutrient criteria documents (July 2002): U.S. Environmental Protection Agency web page, accessed January 7, 2015, at http://www2.epa.gov/nutrient-policy-data/ ecoregional-criteria-documents.

U.S. Environmental Protection Agency, 2013, National recommended water quality criteria: U.S. Environmental Protection Agency web page, accessed April 22, 2018, at https:// www.epa.gov/wqc/national-recommended-water-qualitycriteria-aquatic-life-criteria-table.

U.S. Geological Survey, variously dated, National field manual for the collection of water-quality data: U.S. Geological Survey Techniques of Water-Resources Investigations, book 9 , chaps. A1-A9, v. 2, variously paged. http://pubs. water.usgs.gov/twri9A.
Yetter, S., Bishop, J., Hurteau, S., Chamberlain, S., Nassry, M., Ingram, H., Taylor, A., and Brooks, R., 2013, Allegheny Portage Railroad National Historic Site natural resource condition assessment: National Park Service, Natural Resource Report NPS/ALPO/NRR-2013/727, 255 p. 

For additional information, contact::

Director, Pennsylvania Water Science Center U.S. Geological Survey

215 Limekiln Road

New Cumberland, PA 17070

or visit our website at: https://pa.water.usgs.gov/

Publishing support provided by the West Trenton Publishing Service Center 


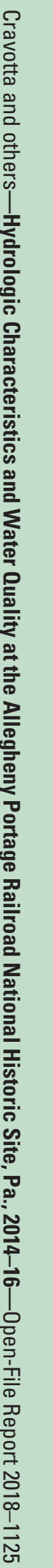

